\title{
Chapter xx \\ CTL ACTION DURING HIV-1 IS DETERMINED VIA INTERACTIONS WITH MULTIPLE CELL TYPES
}

\author{
Seema H. Bajaria and Denise E. Kirschner
}

During HIV-1 infection, interactions between immune cells and virus yield three distinct disease stages: high viral levels in acute infection, immune control in the chronic stage, and AIDS, when CD4 ${ }^{+} \mathrm{T}$ cells fall to extremely low levels. The immune system consists of many players that have key roles during infection. In particular, $\mathrm{CD} 8^{+} \mathrm{T}$ cells are important for killing of virally infected cells as well as inhibition of cellular infection and viral production. Activated $\mathrm{CD} 8^{+} \mathrm{T}$ cells, or cytotoxic $\mathrm{T}$ cells (CTLs) have unique functions during HIV-1, most of which are thought to be compromised during HIV-1 disease progression. Controversy exists regarding priming of CTLs, and our work attempts to address the dynamics occurring during HIV-1 infection. To explore the influence of CD8 ${ }^{+}$ $\mathrm{T}$ cells as determinants in disease progression and issues relating to their priming and activation, we develop a two-compartment ordinary differential equation model describing cellular interactions that occur during HIV- 1 infection. We track $\mathrm{CD} 4^{+} \mathrm{T}$ cells, $\mathrm{CD} 8^{+} \mathrm{T}$ cells, dendritic cells, infected cells, and virus, each circulating between blood and lymphatic tissues. Using parameter estimates from literature, we simulate commonly observed disease patterns. Our results indicate that $\mathrm{CD} 4^{+} \mathrm{T}$ cells as well as dendritic cells likely play a significant role in successful activation of $\mathrm{CD}^{+} \mathrm{T}$ cells into CTLs. Model simulations correlate with clinical data confirming a quantitative relationship between $\mathrm{CD} 4^{+} \mathrm{T}$ cells and $\mathrm{CD} 8^{+}$ T-cell effectiveness.

Keywords: HIV-1, CD8 ${ }^{+}$T cells, CTLs, T-cell help, dendritic cells, immune activation.

\section{INTRODUCTION}

HIV-1 infection leads to the gradual depletion of $\mathrm{CD} 4^{+} \mathrm{T}$ cells over a typical adult disease course in the majority of patients. The mechanisms for this loss remains unclear, and can be attributed to several host and viral factors. Among them is a reduction in thymic production of uninfected cells or infection within the thymus (Douek, 1998; Ye et al., 2002), altered migration of circulation patterns (otherwise 
known as enhanced homing) (Bajaria et al., 2002), a decrease in T-cell life span (enhanced apoptosis) (Hellerstein et al., 1999; McCune et al., 2000), and failure of $\mathrm{CD}^{+}{ }^{+} \mathrm{T}$-cell help to $\mathrm{CD} 8^{+}$T-cells, that normally assist them in performing their full cytolytic function (Shedlock and Shen, 2003; Janssen et al., 2003). We have studied altered homing and enhanced apoptosis in previous models (Bajaria et al., 2002; Ye et al., 2002). We now focus on mechanisms related directly to the function of $\mathrm{CD} 8^{+} \mathrm{T}$ cells.

\subsection{Clinical Progression of HIV-1}

During HIV-1, immune cells and virus interact resulting in three distinct stages of infection (Pantaleo et al., 1993). Acute stage is characterized by high levels of virus, low $\mathrm{CD} 4^{+} \mathrm{T}$-cell counts, and a rapid increase in $\mathrm{CD} 8^{+} \mathrm{T}$-cell counts (Quinn, 1997). The asymptomatic or chronic stage is a function of the host immune system controlling viral growth and spread for an extended period of time, often resulting in undetectable levels of virus, even without the influence of drug therapy. The onset of the AIDS stage occurs when $\mathrm{CD} 4^{+}$T-cell counts fall to extremely low levels, precluding the onset of a variety of opportunistic infections, and eventually death. While this pattern is observed in typical disease progressors, long-term nonprogressors (LTNP) are a small percentage (5\%-10\%) of the infected population who, even without the help of antiretroviral therapy, do not progress to AIDS for over 15 years of infection (Zhang et al., 1997).

$\mathrm{CD} 8^{+} \mathrm{T}$ cells have been shown to be influential in all three disease stages. CD8 ${ }^{+}$T-cell numbers correlate with both viral load (Koup et al., 1994; Borrow, 1994; Ogg et al., 1998) and have a defined correlation with $\mathrm{CD} 4^{+}$T-cell counts (Caruso et al., 1998). Due to the many known activities of $\mathrm{CD} 8^{+} \mathrm{T}$ cells in antiviral immunity, we explore their specific roles during HIV-1 infection.

\subsection{CD8 ${ }^{+}$T-cell Mechanisms During HIV-1 Infection}

$\mathrm{CD} 8^{+} \mathrm{T}$ cells are important in the control of intracellular pathogens, including viruses such as CMV and influenza (McMichael et al., 1983; Webby et al., 2003; Ellefsen et al., 2002). These classically termed "killer" cells have various direct and indirect cytotoxic functions during infection. Upon successful differentiation to cytotoxic T cells (CTLs), CD8 ${ }^{+} \mathrm{T}$ cells can perform cytolytic functions such as direct killing of infected cells expressing foreign proteins and MHC I (McMichael and Rowland-Jones, 2001; Yang et al., 1996; Berke, 1995), and noncytolytic functions such as inhibition of virus infection and production (Walker et al., 1986; Levy et al., 1996). The cytolytic pathway begins when CTLs secret perforin which forms pores in the target cell membrane. Granzymes are then released from CTLs and travel through these pores into target cells, resulting in cell death (McMichael and Rowland-Jones, 2001). A less common mechanism of CTL killing is via Fas 
ligand on CTLs binding to the Fas receptor on target cells and initiating apoptosis (Katsikis et al., 1995).

In addition to the above mechanisms, CTLs prevent infection and virus production through indirect means during HIV-1 infection. CTLs inhibit viral replication through production of cytokines, such as INF- $\gamma$ (Meylan et al., 1993; Emilie et al., 1992). CTLs also produce chemokines that compete with HIV-1 for binding with host cell coreceptors (Barker et al., 1998; Appay et al., 2000). HIV-1 entry into host cells requires binding of gp120 on the HIV-1 envelope to the CD4 receptor and a coreceptor on the surface of the host cell. By producing chemokines that are natural ligands for HIV-1 coreceptors, CTLs can outcompete HIV-1 by successfully preventing binding and subsequent entry of HIV-1 into host cells. Two of the most common coreceptors used by HIV-1 in vivo are CCR5 and CXCR4. Ligands for CCR5 are the CC-chemokines MIP- $1 \alpha$, MIP- $1 \beta$, and RANTES (Cocchi, 1995; Wagner et al., 1998). High levels of these CC-chemokines are secreted from $\mathrm{CD} 8^{+} \mathrm{T}$ cells, and have been shown to be inversely correlated with HIV-1 viral load (Ferbas et al., 2000). CD $8^{+} \mathrm{T}$ cells also produce a soluble $\mathrm{CD} 8^{+} \mathrm{T}$ cell antiviral factor (CAF) distinct from the CC-chemokines (Barker et al., 1998; Moriuchi et al., 1996; Cocchi, 1995; Levy et al., 1996; McMichael and RowlandJones, 2001), which may suppress viral transcription through inhibiting the HIV promoter (Chang et al., 2003). There is evidence of colocalization of granzymes and CC-chemokines inside CTLs, implying that the direct killing and inhibitory pathways are linked such that the same CTL may exert both mechanisms during cytotoxic activities (Wagner et al., 1998).

\subsection{Development of Successful CTLs}

Differentiation of $\mathrm{CD} 8^{+} \mathrm{T}$ cells into activated, HIV-1-specific CTLs usually results from the encounter of $\mathrm{CD} 8^{+} \mathrm{T}$ cells with antigen, commonly found on antigen presenting cells (APCs). However, not all $\mathrm{CD} 8^{+} \mathrm{T}$ cells that are activated by APCs will become fully differentiated CTLs capable of cytotoxic function (AuphanAnezin et al., 2003). Differentiation of $\mathrm{CD} 8^{+} \mathrm{T}$ cells into CTLs that are equipped to perform the functions described above is a result of many interactions involving multiple cell types. There is controversy in the literature as to the importance of $\mathrm{CD}^{+}$T-cell help in the priming of the CTL response. Some have found CD4 ${ }^{+}$ T-cell help to be crucial for both priming and maintenence of the CTL response (Wang and Livingstone, 2003), while some have found CD4 ${ }^{+}$T-cell help to be important only in the memory response (Shedlock and Shen, 2003; Janssen et al., 2003). Furthermore, if $\mathrm{CD} 4^{+} \mathrm{T}$-cell help is necessary, there is speculation about what specific interactions take place between $\mathrm{CD} 4^{+}$and $\mathrm{CD} 8^{+} \mathrm{T}$ cells or whether intermediates are required. We describe below the known functions of dendritic cells and $\mathrm{CD} 4^{+} \mathrm{T}$ cells in the successful development of CTLs. 


\section{Activation by Dendritic Cells}

During viral infection, antigen presentation occurs primarily via dendritic cells and macrophages transporting antigen to T-cell rich areas of LT (Buseyne et al., 2001). In recent years, dendritic cells (DCs) have been identified as the most efficient APCs during the course of HIV-1 disease progression (Bottomly, 1999). Thus, we focus here on the influence of dendritic cells in initiating the immune response and HIV-1-specific CTL activity.

Prior to antigen stimulation, DCs maintain an immature phenotype in the periphery and filter the environment for foreign antigen, but are inefficient at presenting antigen to T cells (Mellman and Steinman, 2001). Immature DCs internalize antigen upon initial encounter, and migrate to the LT undergoing maturation. Maturation is characterized by a decrease in antigen processing capability and an upregulation of costimulatory molecules CD80 and CD86 as well as increased expression of MHC Class II and B7.2 molecules (Sharpe and Freeman, 2002), all of which allows for proper activation of $\mathrm{CD} 4^{+}$and $\mathrm{CD} 8^{+} \mathrm{T}$ cells via DCs (Mellman and Steinman, 2001; Bousso and Robey, 2003; Banchereau and Steinman, 1998; Cella et al., 1997). Thus we track two classes of dendritic cells; the immature DCs (IDCs) that capture antigen in the peripheral blood and mature DCs (MDCs) that present antigen to $\mathrm{T}$ cells in the lymph tissues (LT).

HIV-1 has the capability to exploit this process of antigen presentation to its advantage (Teleshova et al., 2003). During infection, IDCs bind to gp120 on HIV-1 in the periphery via dendritic cell-specific, intracellular adhesion moleculegrabbing nonintegrin (DC-SIGN) (Curtis et al., 1992; Geijtenbeek et al., 2000). IDCs then internalize the virus through macropinocytosis (Sallusto et al., 1995; Baribaud et al., 2001), which extends the short half-life of the virus to several days and protects its infectious capability (Geijtenbeek et al., 2000; Kwon et al., 2002). IDCs then migrate into $\mathrm{LT}$ to present antigen to $\mathrm{CD} 4^{+}$and $\mathrm{CD} 8^{+} \mathrm{T}$ cells (Geijtenbeek et al., 2000). Among the most significant events that follow is DC activation of resting $\mathrm{CD} 4^{+} \mathrm{T}$ cells into HIV-1-specific $\mathrm{T}$ helper cells. This occurs via interaction of CD40-CD40L or secretion of cytokines (Ridge et al., 1998).

Cell-associated virus carried on dendritic cells can infect both resting and activated $\mathrm{CD}^{+} \mathrm{T}$ cells even more efficiently than free virus (McMichael and Rowland-Jones, 2001; Engering et al., 2002; Albert et al., 1998). Upon contact with a dendritic cell, HIV-1 receptors CD4, CCR5, and CXCR4 on T cells colocalize on the cell surface toward the junction of the dendritic cells with $\mathrm{T}$ cells, enhancing the opportunity for successful viral entry (McDonald et al., 2003). There is some evidence that DCs can also become infected, due to their surface expression of both CD4 molecules and the coreceptors CCR5 and CXCR4 (Fong et al., 2002; Patterson et al., 2001). However, this is not thought of as significant in disease progression because the total number of DCs in blood is much less than that of other cell types (Liu, 2001; Grabbe et al., 2000). Additionally, studies have found 
HIV-1-infected DCs in vivo or in vitro are significantly less prevalent than infected $\mathrm{CD}^{+}{ }^{+} \mathrm{T}$ cells (McIlroy et al., 1995; Haase, 1986). Therefore, infection of DCs is not considered in this study.

Here we identify the infection route by which virus is carried from the periphery into LT via dendritic cells. We acknowledge the possibility that there are other mechanisms of virus entry into LT but focus on this as the major pathway.

$\mathrm{CD}_{4}^{+}$T-cell Help to CD8 ${ }^{+}$T Cells

$\mathrm{CD}^{+} \mathrm{T}$ cells that become activated are termed helper $\mathrm{T}$ cells in that they play a significant role in aiding CTLs to perform their effector function. CD4 ${ }^{+} \mathrm{T}$ cells have been implicated in both the initial priming (Wang and Livingstone, 2003) as well as long-term memory CD8 ${ }^{+}$T-cell response (Janssen et al., 2003; Shedlock and Shen, 2003). Thus, since CD4 ${ }^{+} \mathrm{T}$ cells decline significantly early in the infection process, the $\mathrm{CD} 8^{+} \mathrm{T}$-cell response is adversely affected during both shortand long-term immunity. HIV-1-specific helper T cells correlate strongly with HIV1-specific CTLs that have antiviral activity (Kalams and Walker, 1998; Kalams et al., 1999).

The helper function of $\mathrm{CD} 4^{+} \mathrm{T}$ cells can be attributed to both release of cytokines as well as direct cell-cell interactions. Activated $\mathrm{CD} 4^{+} \mathrm{T}$ cells release IL-2, a cytokine that induces T-cell proliferation, thus expanding the populations of both $\mathrm{CD} 4^{+}$and $\mathrm{CD} 8^{+} \mathrm{T}$ cells. However, $\mathrm{CD} 4^{+} \mathrm{T}$ cells that have encountered HIV-1 on dendritic cells express various activation markers that can further interact with either dendritic cells or $\mathrm{CD} 8^{+} \mathrm{T}$ cells. This initiates the stages of $\mathrm{CD} 8^{+}$ T-cell activation that lead to fully differentiated CTLs. CD40L, expressed on the surface of activated CD4 ${ }^{+} \mathrm{T}$ cells, is important for effector function in immunity (van Essen et al., 1995), particularly during HIV-1 infection (Bennett et al., 1998; Ridge et al., 1998; Schoenberger et al., 1998). This has been shown in experiments in which CD40L inhibition results in a population of unprimed CD8 ${ }^{+} \mathrm{T}$ cells (Schoenberger et al., 1998). The interaction of CD40L on activated $\mathrm{T}$ cells with CD40 on DCs further stimulates virus-carrying DCs to activate CD8 ${ }^{+} \mathrm{T}$ cells (Cella et al., 1996). Once activated, $\mathrm{CD} 4^{+} \mathrm{T}$ cells can also have direct interaction with CD8 ${ }^{+} \mathrm{T}$ cells (Bourgeois et al., 2002). Thus, CD4 ${ }^{+}$T-cell help to CTLs is ultimately mediated by the interplay between $\mathrm{CD} 4^{+} \mathrm{T}$ cells and DCs (Caux et al., 1994). The HIV-1 envelope protein Nef can also interfere with the antigen presentation pathway by intersecting CD40-CD40L activation (Pope, 2003; Andrieu et al., 2001).

HIV-1-specific CTL killing and inhibition is crucial even as early as the acute stage of infection (Zajac et al., 1998). Throughout chronic infection, CD4 ${ }^{+} \mathrm{T}$ cells lose their ability to dictate functionality of $\mathrm{CD} 8^{+} \mathrm{T}$ cells towards eliminating the virus, or ensuring specificity of adaptive immunity through a steady decline in $\mathrm{CD}^{+}$T-cell numbers (McMichael and Rowland-Jones, 2001; Appay et al., 2000; 
Lieberman et al., 2001). This effect would be even more pronounced however in the absence of CTLs specific for HIV-1 activated during acute infection. Even though there may be a significant proportion of $\mathrm{CD} 8^{+} \mathrm{T}$ cells that are activated, virus can still persist without specific T-cell immunity due to loss of instructional CD4 ${ }^{+}$ T helper cells (Goulder et al., 2000). A higher frequency of HIV-1-specific CD4 ${ }^{+}$ T-cell responses is characteristic of LTNPs as compared to typical progressors (Pitcher et al., 1999). There exists both a quantitative and qualitative correlation between the specificity of the $\mathrm{CD} 4^{+}$T-cell response during HIV-1 infection and the functionality of the $\mathrm{CD} 8^{+}$T-cell response (McMichael and Rowland-Jones, 2001).

\subsection{Failure of CTLs in Controlling Infection}

There are a number of possibilities for the observed decline in CTL immunity in end-stage disease. In addition to the loss in the number of CTLs, CTL dysfunction could be due to the presence of a high number of activated cells without functionality (Kostense et al., 2002; Trimble and Lieberman, 1998), alterations in cell distributions at infected sites (Pantaleo et al., 1997b), or virus mutation to evade CTLs (Phillips et al., 1991).

CTLs may not necessarily traffick to sites of virus replication (Pantaleo et al., 1997b; Wherry et al., 2003). CCR7 receptors are generally found on molecules that travel to lymphoid tissue (Forster et al., 1999). HIV-1-specific CTLs are characterized as CCR7-, thus lacking the capability for travel to LT, the site of most viral infection and production (Chen et al., 2001). This finding is supplemented by evidence that perforin is not found in the lymph nodes of infected patients in both acute and chronic disease and perforin and granzymes are not colocalized in CTLs found in the LT (Andersson et al., 1999, 2002), both suggesting that CTLs are not in the anatomic location where they are most needed.

HIV-1-specific CTLs are lower in number than CTLs detected during other viral infections such as Epstein-Barr virus or cytomegalovirus (CMV) (Gillespie et al., 2000; Hislop et al., 2001). This may be a key reason for better immune control observed in other infections. Additionally, there are functional differences between HIV-1-specific CTLs and for example, CMV-specific CTLs. HIV-1-specific $\mathrm{CD} 8^{+} \mathrm{T}$ cells express lower levels of perforin compared to CMV-specific cells (Papagno et al., 2002). HIV-1-specific CTLs are also in a less mature state as compared to other CTLs, and their killing and inhibitory capacities are reduced (van Baarle et al., 2002). In this work, we assume activated $\mathrm{CD} 4^{+} \mathrm{T}$ cells are

HIV-1-specific and correlate our simulation results with data on HIV-1-specific $\mathrm{CD} 4^{+}$and $\mathrm{CD} 8^{+} \mathrm{T}$ cells. 


\section{MODEL OF HIV-1 INFECTION}

We develop a mathematical model to elucidate the role of $\mathrm{CD}^{+} \mathrm{T}$ cells in various stages of HIV-1 infection as well as to explore priming and differentiation of HIV-1-specific CTLs. The most common clinical markers for HIV-1 disease progression are $\mathrm{CD}^{+}{ }^{+} \mathrm{T}$-cell and viral load measurements from the blood. However, most lymphocytes (98\%) reside in lymph tissues and circulate constantly between LT and blood (Haase, 1999). Therefore, we build a two-compartment model of HIV-1 infection in blood and lymph tissues (Figure 1), similar to our previous work (Bajaria et al., 2002). We account for the following populations in both the peripheral blood and lymph tissues: resting and activated $\mathrm{CD} 4^{+} \mathrm{T}$ cells, resting and activated $\mathrm{CD}^{+} \mathrm{T}$ cells, infected $\mathrm{CD} 4^{+} \mathrm{T}$ cells, virus, and dendritic cells.

\subsection{Model Equations}

Using thirteen nonlinear ordinary differential equations, we tracked dynamics of $\mathrm{CD}^{+}\left(T_{4}\right)$ and $\mathrm{CD}^{+}\left(T_{8}\right) \mathrm{T}$ cells circulating between blood $(\mathcal{B})$ and lymph tissue $(\mathcal{L})$ compartments. During infection, virus levels are monitored in both the blood $\left(V_{\mathcal{B}}\right)$ as well as lymph tissues $(V)$, together with infected cells $(I)$ and activated $\mathrm{CD}^{+}\left(T_{H}\right)$ and $\mathrm{CD}^{+}\left(T_{C}\right) \mathrm{T}$ cells in the lymph tissues, MDCs in the lymph tissues $(D)$ and IDCs in the blood $\left(D_{B}\right)$. Equations for the model system are as follows:

$$
\begin{aligned}
\frac{d T_{4}}{d t}= & S_{4}-\mu_{4} T_{4}-\frac{r D T_{4}}{D+f_{1}}\left(\frac{f_{5}}{V+f_{5}}\right)-k_{1}\left(\frac{c_{1}}{T_{C}+c_{1}}\right) V T_{4} \\
& -k_{2}\left(\frac{c_{2}}{T_{C}+c_{2}}\right) D T_{4}+\frac{p_{4} T_{H} T_{4}}{T_{H}+f_{2}}+\alpha e_{B} T_{4 B}-e_{L} T_{4} \\
\frac{d T_{4 B}}{d t}= & \beta e_{L} T_{4}-e_{B} T_{4 B} \\
\frac{d T_{H}}{d t}= & \frac{r D T_{4}}{D+f_{1}}\left(\frac{f_{5}}{V+f_{5}}\right)-\mu_{H} T_{H}-k_{3}\left(\frac{c_{3}}{T_{C}+c_{3}}\right) V T_{H} \\
& -k_{4}\left(\frac{c_{4}}{T_{C}+c_{4}}\right) D T_{H}+\alpha e_{B} T_{H B}-e_{L} T_{H} \\
\frac{d T_{H B}}{d t}= & \beta e_{L} T_{H}-e_{B} T_{H B} \\
\frac{d I}{d t}= & k_{1}\left(\frac{c_{1}}{T_{C}+c_{1}}\right) V T_{4}+k_{2}\left(\frac{c_{2}}{T_{C}+c_{2}}\right) D T_{4}+k_{3}\left(\frac{c_{3}}{T_{C}+c_{3}}\right) V T_{H} \\
& +k_{4}\left(\frac{c_{4}}{T_{C}+c_{4}}\right) D T_{H}-\mu_{I} I-\kappa T_{C} I \\
\frac{d V}{d t}= & N\left(\frac{c_{5}}{T_{C}+c_{5}}\right) \mu_{I} I-\mu_{V} V \\
\frac{d V_{B}}{d t}= & \beta e_{V} V-\mu_{V} V_{B}
\end{aligned}
$$




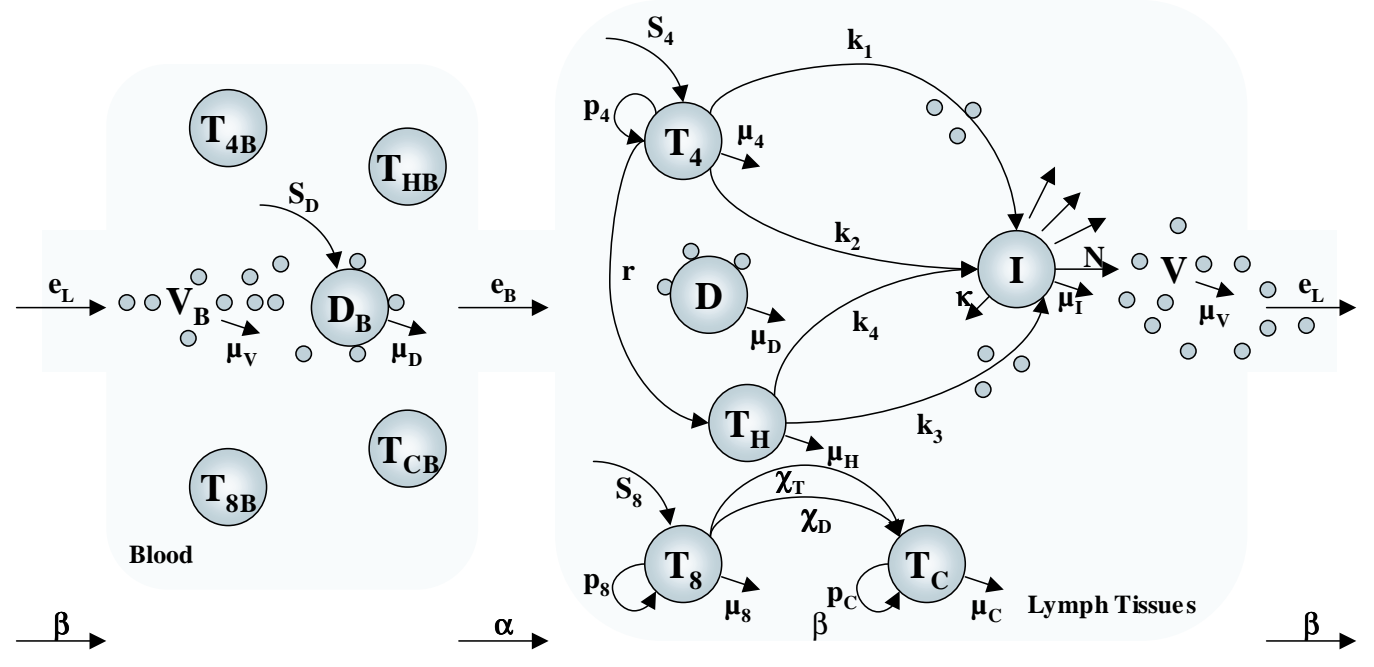

Fig. 1. Two-compartment HIV-1 infection model. The model developed here explores mechanisms of HIV-1 disease progression based on the interactions of a single viral strain $(V(t))$ of HIV-1 with resting $\left(T_{4}(t)\right)$ and activated $\left(T_{H}(t)\right)$ subclasses of $\mathrm{CD}^{+} \mathrm{T}$ cells at rates $k_{1}$ and $k_{3}$, respectively. This leads to the development of infected cells $(I(t))$, which are also created by infection via virus $\left(V_{B}(t)\right)$ on IDCs from the blood $\left(D_{B}(t)\right.$ ) (at rates $k_{2}$ and $k_{4}$ ). Upon migration into the LT, IDCs mature into MDCs $(D(t))$ and activate $T_{4}$ into $T_{H}$ at rate $\mathrm{r}$. Infection directly produces actively infected $(I(t))$ cells that are assumed to be present predominantly in the LT compartments, owing to the assumption that infected cells in the blood (containing only $2 \%$ of all $\mathrm{T}$ cells) constitute a relatively small contribution to overall infection, and that most HIV-1 replication occurs in the LT (Richman, 2000). $\mathrm{CD}^{+} \mathrm{T}$ cells $\left(T_{8}(t)\right)$ are activated into CTLs $\left(T_{C}(t)\right)$ in the LT due to interaction with either $T_{H}(t)$ (at rate $\chi_{T}$ ) or MDCs $(D(t))$ (at rate $\chi_{D}$ ). CTLs can kill infected cells (at rate $\kappa$ ) and inhibit infection of $T_{4}$ cells (saturating at $c_{1}$ and $c_{2}$ ) and $T_{H}$ cells (saturating at $c_{3}$ and $c_{4}$ ), and inhibit virus production from $I$ (saturating at $c_{5}$ ). CTLs can proliferate in response to IL-2 secreted from $T_{H}$ cells (at rate $p_{C}$ ). Resting and activated $\mathrm{CD} 4^{+}$and $\mathrm{CD} 8^{+} \mathrm{T}$ cells proliferate at rates $p_{4}$ and $p_{8}$ and circulate between blood $(\mathcal{B})$ and LT $(\mathcal{L})$ at rates $e_{B}$ and $e_{L}$ scaled by $\alpha$ and $\beta$. All initial conditions and parameters are described in Tables 1-3. 


$$
\begin{aligned}
\frac{d T_{8}}{d t}= & S_{8}-\mu_{8} T_{8}-\chi_{D} \frac{T_{H}}{T_{H}+f_{3}} D T_{8}-\chi_{T} T_{H} T_{8}+\frac{p_{8} T_{H} T_{8}}{T_{H}+f_{4}} \\
& +\alpha e_{B} T_{8 B}-e_{L} T_{8} \\
\frac{d T_{8 B}}{d t}= & \beta e_{L} T_{8}-e_{B} T_{8 B} \\
\frac{d T_{C}}{d t}= & \chi_{D} \frac{T_{H}}{T_{H}+f_{3}} D T_{8}+\chi_{T} T_{H} T_{8}-\mu_{C} T_{C}+p_{C} \frac{T_{H}}{T_{H}+f_{6}} T_{C} \\
& +\omega \alpha e_{B} T_{C B}-e_{L} T_{C} \\
\frac{d T_{C B}}{d t}= & \beta e_{L} T_{C}-\omega e_{B} T_{C B} \\
\frac{d D}{d t}= & \alpha \delta_{B} \frac{V_{B}}{V_{B}+\psi} D_{B}+\lambda_{L} \frac{V}{V+\phi_{L}} D-\mu_{D} D \\
\frac{d D_{B}}{d t}= & S_{D}-\mu_{D} D_{B}+\lambda_{B} \frac{V_{B}}{V_{B}+\phi_{B}} D_{B}-\delta_{B} \frac{V_{B}}{V_{B}+\psi} D_{B}
\end{aligned}
$$

Equations (1) and (8) describe resting $\mathrm{CD} 4^{+}$and $\mathrm{CD} 8^{+}$T-cell populations in the lymph tissues. Their populations depend on influx from the blood at rate $e_{B}$ (scaled by $\alpha$ for compartmental exchange) and loss due to emigration at rate $e_{L}$. Equations (2) and (9) describe resting $\mathrm{CD} 4^{+}$and $\mathrm{CD} 8^{+} \mathrm{T}$-cell populations in the blood and have similar circulation terms (scaled by $\beta$ for entry into the blood). The source of $\mathrm{CD} 4^{+}\left(S_{4}\right)$ and $\mathrm{CD} 8^{+}\left(S_{8}\right)$ T cells represents new constant input from the thymus while their half-lives are representated by the decay rates $\mu_{4}$ and $\mu_{8}$, respectively. Contact between a dendritic cell and a resting $\mathrm{CD} 4^{+} \mathrm{T}$-cell can result in either activation into $\mathrm{CD} 4^{+} \mathrm{T}$ helper cells $\left(T_{H}\right)$ at rate $r$ (saturating at $f_{1}$ ) or infection at rate $k_{2}$. Infection can also result directly by meeting virus at rate $k_{1}$. Resting cells can also proliferate at rate $p_{4}$ dependent on the amount of IL-2 in the environment secreted from $\mathrm{T}$ helper cells $\left(T_{H}\right)$, which we assume is a proportion relative to $T_{H}$ cells. Activation can be hindered by Nef interference with the CD40CD40L pathway of DC activation (saturating at $f_{5}$ ) (Pope, 2003). Activated CD4 ${ }^{+}$ $\mathrm{T}$ cells $\left(T_{H}\right)$ have a death rate $\left(\mu_{H}\right)$, and become infected by directly meeting virus $\left(k_{3}\right)$ or through presentation of virus by a dendritic cell (at rate $k_{4}$ ) (Douek et al., 2002). Similar circulation terms for $T_{H}$ cells describe emigration from and to their counterparts in the blood ( $T_{H B}$ in Equation 4). Infected cells result from any of the pathways described above and are subject to a death rate $\mu_{I}$. When dendritic cells come into contact with resting $\mathrm{CD} 8^{+} \mathrm{T}$ cells at rate $\chi_{D}$, new CTLs are created, an effect that is enhanced in the presence of $T_{H}$ cells, saturating at rate $f_{3}$. CD $8^{+} \mathrm{T}$ cells can also become activated through direct contact with a $T_{H}$ at rate $\chi_{T}$ because $\mathrm{CD} 8^{+} \mathrm{T}$ cells transiently express $\mathrm{CD} 40$ after activation (Bourgeois et al., 2002). The levels of resting CD ${ }^{+} \mathrm{T}$ cells are supplemented by proliferation (at rate $p_{8}$ ), also in response to IL-2 secreted from $T_{H}$ cells. There is evidence that pre-terminally differerentiated CTLs can proliferate (Champagne et al., 2001) in response to IL-2 (Jin et al., 1998) and the majority of HIV-1specific $\mathrm{CD} 8^{+} \mathrm{T}$ cells are at an intermediate stage of differentiation (Appay et al., 
2002; Champagne et al., 2001), thus we include proliferation of CTLs occurring at rate $p_{C}$. This effect saturates at rate $f_{6}$, since IL-2 expandable CTL responses are reduced in end-stage HIV-1 infection (Jin et al., 1998). Because there is evidence that HIV-1-specific CTLs lack the capacity to home to the LT during infection (Chen et al., 2001), we include a factor $\omega$ as the percentage of CTLs that circulate back into the LT from the blood. IDCs are initially present in homeostasis in blood with source $S_{D}$ and death rate $\mu_{D}$. They are recruited into LTs at rate $\lambda_{B}$ in response to virus in the blood $\left(V_{B}\right)$, a process which saturates at $\phi_{B}$. Blood IDCs take up virus and migrate to lymph tissues at rate $\delta_{B}$, which also saturates at $\psi$. There is also a recruitment rate $\left(\lambda_{L}\right)$ of MDCs into the lymph tissues in response to viral stimulus or inflammation, an activity which saturates at $\phi_{L}$. Virus $(V)$ is produced in the LT from infected cells (at rate $N$ ) and has a short half-life $\left(\mu_{V}\right)$. Virus in the blood flows in from the LT $\left(e_{V}\right)$, and is lost to natural death $\left(\mu_{V}\right)$.

Direct cell-to-cell contact is necessary for CTLs to eliminate infected cells (Folkvord et al., 2003). We incorporate clearance of infected cells due to CTLs (at rate $\kappa$ ) acting through the perforin/granzyme pathway and/or Fas pathway. As of yet there is little evidence as to what proportion of cells are eliminated by Fasmediated apoptosis and which by perforin and granzyme killing; only that both result in target cell death. We include these cytolytic activities occurring in the lymph tissues only, concurrent with previous data that most viral replication and production processes occur in the LT (Haase, 1999). Free virus is not a common target for clearance by CTLs and thus the virus equation only includes a loss term due to half-life of the virus. CTLs inhibit both viral infection and virus production. Low CTL counts allow full infectivity and virus production, whereas increased CTL levels impair these infection processes. Thus, the inhibitory effect of CC-chemokines is captured by CTLs decreasing infection rates of $\mathrm{CD} 4^{+} \mathrm{T}$ cells $\left(k_{1}\right.$ through $\left.k_{4}\right)$ and the rate of virus production from infected cells $(N)$, an effect that saturates at a maximum number of CTLs $\left(c_{1}\right.$ through $\left.c_{5}\right)$.

\subsection{Parameter Estimation}

Table 1 presents initial conditions for the thirteen variables in our model system. In the absence of infection, $\mathrm{CD} 4^{+} \mathrm{T}$ cells, $\mathrm{CD} 8^{+} \mathrm{T}$ cells, and dendritic cells exhibit homeostasis. Initial values for infected cell populations and virus are all zero to ensure that initially there is no infection before virus is introduced into the system. We account only for recently emigrated virus-carrying IDCs from the blood, without considering any background level of MDCs in the lymph tissues. Thus the initial condition for MDCs in the LT is zero.

Tables 2 and 3 present parameter values used in our simulations. Infection rates $\left(k_{1}\right.$ through $\left.k_{4}\right)$ are estimated using LHS analysis (discussed below) as no data exist on these processes. We estimate, however, that infection of $\mathrm{CD} 4^{+} \mathrm{T}$ 
helper cells (at rates $k_{3}$ and $k_{4}$ ) highly exceeds that of resting cells (at rates $k_{1}$ and $k_{2}$ ) due to high susceptibility of activated cells to infection (Gougeon and Montagnier, 1993). During contact with MDCs, HIV-1 receptors colocalize on the surface of T cells (Douek et al., 2002; McDonald et al., 2003). Additionally, Tat, a gene expressed during HIV-1 infection, exploits immature dendritic cell activities. Tat mediates chemokine upregulation in immature dendritic cells, causing enhanced recruitment of activated T cells (Izmailova et al., 2003). Thirdly, virus that has been taken up by IDCs has a longer half-life than free virus. Lastly, the kinetics of viral transfer from dendritic cells to $\mathrm{T}$ cells is much greater than that of free virus to T cells (Gummuluru et al., 2003). This last feature is crucial to infection due to the short half-life of activated cells (Gougeon and Montagnier, 1993). These processes make trans-infection of $\mathrm{CD} 4^{+} \mathrm{T}$ cells by $\mathrm{DCs}$ very efficient, and the infection rate of cell-associated virus is estimated to be much higher than that by free virus (i.e. $k_{4}>k_{3}>k_{2}>k_{1}$ ). Similarly, death rates of activated cells are estimated as greater than that of resting cells, with free virus having the shortest half-life (i.e. $\mu_{V}>\mu_{H}$ and $\mu_{C}>\mu_{4}$ and $\mu_{8}$ ). Infected cells are assumed to be productively infected and able to actively produce virus over their lifespan (Haase, 1999). Productively infected cells produce anywhere from 100-1000 virions per cell (Haase, 1999), and we use 800 virions/cell as the baseline value in our model simulations. This parameter has been shown to have a significant impact on the dynamics of infection (Bajaria et al., 2002). Half-saturation constants for the effect of T-cell help to CD8 ${ }^{+} \mathrm{T}$ cells $\left(f_{3}\right)$, the strength of CTL inhibition $\left(c_{1}\right.$ through $c_{5}$ ), the impact of dendritic cells on $\mathrm{CD} 4^{+}$T-cell activation $\left(f_{1}\right)$, inhibition of CD4 $4^{+}$T-cell activation by Nef-induced interference $\left(f_{5}\right)$ and the influence of IL-2 on T-cell proliferation $\left(f_{2}, f_{4}, f_{6}\right)$ have also been estimated. $\alpha$ and $\beta$ are included as compartmental parameters scaling exchange between LT and blood compartments, since blood cells are measured per $\mathrm{mm}^{3}$ of blood and the LT in total cells.

\section{Uncertainty and Sensitivity Analysis}

There are several parameters in our model for which no in vivo nor human data exists. By comparison with non-human data, in vitro experiments, and studies of other pathogens, we can estimate a wide range of possible values for each unknown parameter. Using Latin hypercube sampling (LHS), we find values for those parameters for which reported estimates do not exist (Blower and Dowlatabadi, 1994). This process generates a hypercube through a random combination of parameter values from each estimated range; simulations are then performed for each sample. Output is compared with clinical data on $\mathrm{T}$ cells and viral load, and we ultimately choose those parameters for which model simulations exhibit the best fit with known output variables. We further extend this LHS method to test system output sensitivity to various key parameters. By examining the effect each 
key parameter has on the outcome variable (in this case viral load) using a partial rank correlation (PRC), we can assess the relative influence of each parameter on system dynamics (e.g. (Blower and Dowlatabadi, 1994)). In fact, those parameters that have significant PRC values have been shown to be bifurcation parameters. Using the LHS/PRC method to study sensitivity and identify bifurcations is a tool to study differences in disease outcomes.

Table 1. Initial conditions for HIV-1 model

\begin{tabular}{|c|c|c|c|c|}
\hline Variable & Definition & Value & Units & Reference \\
\hline \multicolumn{5}{|c|}{ Populations in $L T$} \\
\hline$T_{4}(0)$ & Resting $\mathrm{CD} 4^{+} \mathrm{T}$ cells & $2 \times 10^{11}$ & cells & 1 \\
\hline$T_{H}(0)$ & Activated $\mathrm{CD} 4^{+} \mathrm{T}$ cells & 0 & cells & \\
\hline$I(0)$ & Infected $\mathrm{CD} 4^{+} \mathrm{T}$ cells & 0 & cells & \\
\hline$V(0)$ & Virus & 0 & viral RNA & \\
\hline$T_{8}(0)$ & Resting $\mathrm{CD}^{+} \mathrm{T}$ cells & $1 \times 10^{11}$ & cells & 1 \\
\hline$T_{C}(0)$ & Activated $\mathrm{CD}^{+} \mathrm{T}$ cells & 0 & cells & \\
\hline$D(0)$ & Dendritic cells & 0 & cells & \\
\hline \multicolumn{5}{|c|}{ Populations in blood } \\
\hline$T_{4 B}(0)$ & Resting $\mathrm{CD}^{+}{ }^{+} \mathrm{T}$ cells & 1000 & cells $/ \mathrm{mm}^{3}$ & 1 \\
\hline$T_{8 B}(0)$ & Activated $\mathrm{CD}^{+} \mathrm{T}$ cells & 0 & cells $/ \mathrm{mm}^{3}$ & \\
\hline$V_{B}(0)$ & Virus concentration & 10 & viral $\mathrm{RNA} / \mathrm{ml}$ & \\
\hline$T_{8}(0)$ & Resting $\mathrm{CD} 8^{+} \mathrm{T}$ cells & 500 & cells $/ \mathrm{mm}^{3}$ & 1 \\
\hline$T_{C}(0)$ & Activated $\mathrm{CD}^{+} \mathrm{T}$ cells & 0 & cells $/ \mathrm{mm}^{3}$ & \\
\hline$D_{B}(0)$ & Dendritic cells & 20 & cells $/ \mathrm{mm}^{3}$ & 2 \\
\hline
\end{tabular}

1 (Haase, 1999)

2 (Barron et al., 2003)

\section{RESULTS}

Using the equations and parameters described above, we simulate the three distinct stages of typical disease progression. We then use this positive control to vary parameters related to $\mathrm{CD} 8^{+} \mathrm{T}$-cell dynamics and examine effects to the typical HIV-1 disease course.

\subsection{Healthy Control}

We simulate total $\mathrm{CD} 4^{+}$and $\mathrm{CD} 8^{+} \mathrm{T}$ cells in healthy, uninfected individuals as a negative control. In healthy individuals, total $\mathrm{CD} 4^{+} \mathrm{T}$-cell counts in the LT 
Table 2. Parameter values for homeostasis

\begin{tabular}{|c|c|c|c|}
\hline Parameter & Value & Units & Reference \\
\hline \multicolumn{4}{|l|}{ Scaling between compartments } \\
\hline Blood to $\operatorname{LT}(\alpha)$ & $5 \times 10^{6}$ & $\mathrm{~mm}^{3}$ or $\mu \mathrm{l}$ & \\
\hline LT to blood $(\beta)$ & $2 \times 10^{-7}$ & $\mathrm{~mm}^{3}$ or $\mu \mathrm{l}$ & \\
\hline \multicolumn{4}{|l|}{ Circulation of $T$ cells } \\
\hline LT to blood $\left(e_{L}\right)$ & 0.01 & /day & 1 \\
\hline Blood to $\mathrm{LT}\left(e_{B}\right)$ & 0.4 & /day & 1 \\
\hline \multicolumn{4}{|l|}{ Source terms } \\
\hline $\mathrm{CD}^{+} \mathrm{T}$ cells into $\mathrm{LT}\left(S_{4}\right)$ & $4 \times 10^{8}$ & cells/day & 2 \\
\hline $\mathrm{CD}^{+} \mathrm{T}$ cells into $\mathrm{LT}\left(S_{8}\right)$ & $2 \times 10^{8}$ & cells/day & 2 \\
\hline Dendritic cells into blood $\left(S_{D}\right)$ & 0.1 & cells/day & estimated \\
\hline \multicolumn{4}{|l|}{ Death rates } \\
\hline Resting $\mathrm{CD} 4^{+} \mathrm{T}$ cells $\left(\mu_{4}\right)$ & 0.002 & /day & 3 \\
\hline Resting CD8 ${ }^{+} \mathrm{T}$ cells $\left(\mu_{8}\right)$ & 0.002 & /day & 3 \\
\hline Dendritic cells $\left(\mu_{D}\right)$ & 0.005 & /day & estimated \\
\hline
\end{tabular}

1 (Sprent, 1973; Sprent and Basten, 1973)

2 (Haase, 1999)

3 (Richman, 2000)

are about $2 \times 10^{11}$ cells and 1000 cells $/ \mu$ in the blood (Haase, 1999). The ratio of $\mathrm{CD} 4^{+} \mathrm{T}$ cells to $\mathrm{CD} 8^{+} \mathrm{T}$ cells is approximately $2: 1$ in healthy individuals in both blood and LT (Haase, 1999; Rosenberg et al., 1998). Our model simulations correlate with estimates of $10^{11} \mathrm{CD} 8^{+}$T-cells in the LT and 500 cells/ $\mu \mathrm{l}$ of blood from (Haase, 1999) (data not shown). There is a median 14-20 dendritic cells per milliliter of blood in healthy individuals (Barron et al., 2003). All infected cell populations and dendritic cells in the lymph tissues are set to zero prior to infection.

\subsection{Typical Progression of HIV-1}

$C D 8^{+} T$ cells in Acute Infection

The acute stage of HIV-1 disease is characterized by extremely low CD4 ${ }^{+} \mathrm{T}$ cell counts and high levels of virus, often higher than $10^{6}$ copies $/ \mathrm{ml}$ of blood. Consequently, activation and differentiation of large numbers of $\mathrm{CD}^{+} \mathrm{T}$ cells into CTLs results in a significant number that provide killing and inhibitory activities towards viral infection and production. A strong CTL response coincides with resolution of high viremia in the acute stage whereby virus levels decrease approximately 100-fold (McMichael and Rowland-Jones, 2001; Koup et al., 1994; 
Table 3. Parameter values for infection

\begin{tabular}{|c|c|c|}
\hline Parameter & Value & Units \\
\hline \multicolumn{3}{|l|}{ Death rates } \\
\hline Activated $\mathrm{CD} 4^{+} \mathrm{T}$ cells $(\mathrm{LT})\left(\mu_{H}\right)$ & 0.5 & /day \\
\hline Activated $\mathrm{CD} 8^{+} \mathrm{T}$ cells $(\mathrm{LT})\left(\mu_{C}\right)$ & 1.5 & /day \\
\hline Infected CD $4^{+} \mathrm{T}$ cells $\left(\mu_{I}\right)$ & 0.1 & /day \\
\hline Free virus $\left(\mu_{V}\right)$ & 3.0 & /day \\
\hline \multicolumn{3}{|l|}{ Infection rates } \\
\hline Resting CD $4^{+} \mathrm{T}$ cells by virus $\left(k_{1}\right)$ & $2.0 \times 10^{-14}$ & /day-virion \\
\hline Resting CD $4^{+} \mathrm{T}$ cells by dendritic cells $\left(k_{2}\right)$ & $4.0 \times 10^{-13}$ & /day-cell \\
\hline Activated $\mathrm{CD} 4^{+} \mathrm{T}$ cells by virus $\left(k_{3}\right)$ & $4.0 \times 10^{-11}$ & /day-virion \\
\hline Activated $\mathrm{CD} 4^{+} \mathrm{T}$ cells by dendritic cells $\left(k_{4}\right)$ & $2.0 \times 10^{-7}$ & /day-cell \\
\hline Number of virions produced from infected cells $(N)$ & 800 & virions/cell \\
\hline \multicolumn{3}{|l|}{ Activation/Differentiation/Proliferation rates } \\
\hline Activation of $\mathrm{CD} 4^{+} \mathrm{T}$ cells by dendritic cells $(r)$ & 0.01 & /day \\
\hline Differentiation of $\mathrm{CD} 8^{+} \mathrm{T}$ cells by dendritic cells $\left(\chi_{D}\right)$ & $1.0 \times 10^{-10}$ & /day-cell \\
\hline Differentiation of $\mathrm{CD} 8^{+} \mathrm{T}$ cells by $\mathrm{CD} 4^{+} \mathrm{T}$ helper cells $\left(\chi_{T}\right)$ & $8.0 \times 10^{-11}$ & /day-cell \\
\hline Proliferation of $\mathrm{CD} 4^{+} \mathrm{T}$ cells $\left(p_{4}\right)$ & 0.02 & /day \\
\hline Proliferation of $\mathrm{CD}^{+} \mathrm{T}$ cells $\left(p_{8}\right)$ & 0.02 & /day \\
\hline Proliferation of CTLs $\left(p_{C}\right)$ & 0.5 & /day \\
\hline \multicolumn{3}{|l|}{ Half-saturation constants } \\
\hline $\mathrm{CD} 4^{+} \mathrm{T}$ cells on activation $\left(f_{1}\right)$ & $10^{11}$ & cells \\
\hline $\mathrm{CD} 4^{+} \mathrm{T}$ cells on proliferation $\left(f_{2}\right)$ & $10^{7}$ & cells \\
\hline $\mathrm{CD} 4^{+}$T-cell help to $\mathrm{CD} 8^{+}$differentiation $\left(f_{3}\right)$ & $10^{4}$ & cells \\
\hline $\mathrm{CD}^{+} \mathrm{T}$ cells on proliferation $\left(f_{4}\right)$ & $8.0 \times 10^{6}$ & cells \\
\hline Virus on interference with activation $\left(f_{5}\right)$ & $8.0 \times 10^{6}$ & cells \\
\hline Migration of dendritic cells to LT $(\psi)$ & 1.0 & virus \\
\hline Recruitment of dendritic cells to LT $\left(\phi_{L}\right)$ & 100.0 & virus \\
\hline Recruitment of dendritic cells to blood $\left(\phi_{B}\right)$ & 10.0 & virus \\
\hline \multicolumn{3}{|l|}{ Inhibition constants } \\
\hline $\mathrm{CD} 4^{+} \mathrm{T}$-cell infection by virus $\left(c_{1}\right)$ & $10^{8}$ & cells \\
\hline $\mathrm{CD} 4^{+} \mathrm{T}$-cell infection by dendritic cells $\left(c_{2}\right)$ & $10^{6}$ & cells \\
\hline $\mathrm{CD} 4^{+} \mathrm{T}$ helper cell infection by virus $\left(c_{3}\right)$ & $10^{8}$ & cells \\
\hline $\mathrm{CD} 4^{+} \mathrm{T}$ helper cell infection by dendritic cells $\left(c_{4}\right)$ & $10^{7}$ & cells \\
\hline Virus production from infected cells $\left(c_{5}\right)$ & $10^{8}$ & cells \\
\hline Clearance rate of infected cells $(\kappa)$ & $9.0 \times 10^{-10}$ & /day-cell \\
\hline \multicolumn{3}{|l|}{ Circulation/Migration/Recruitment } \\
\hline Proportion of CTLs that travel to LT from blood $(\omega)$ & 0.002 & scalar \\
\hline Circulation of virus (LT to blood) $\left(e_{V}\right)$ & 0.8 & /day \\
\hline Migration of blood DC to LT $\left(\delta_{B}\right)$ & 0.0448 & /day \\
\hline Recruitment of dendritic cells to LT $\left(\lambda_{L}\right)$ & 0.007 & /day \\
\hline Recruitment of dendritic cells to blood $\left(\lambda_{B}\right)$ & 0.04 & /day \\
\hline
\end{tabular}

All parameters were estimated except $\mu_{I}$ (Cavert et al., 1997), $\mu_{V}$ (Perelson et al., 1996; Stafford et al., 2000), and $N$ (Haase, 1999). 
Safrit and Koup, 1995). Additionally, the CD4:CD8 ratio is inverted from 2:1 to 1:2 after seroconversion (Rosenberg et al., 1998; Schacker et al., 1996).

A

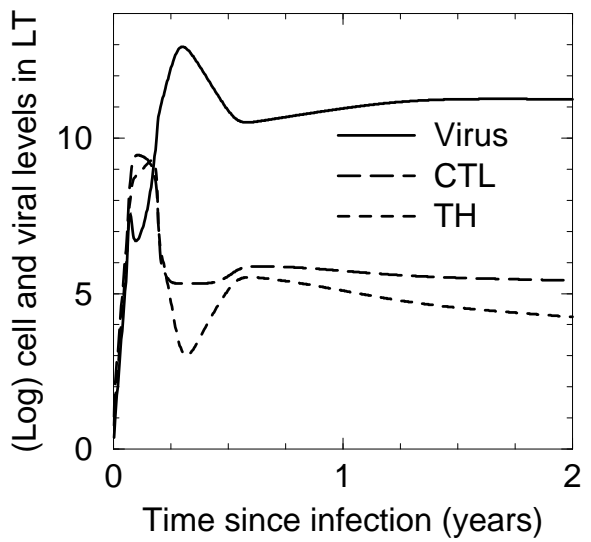

B

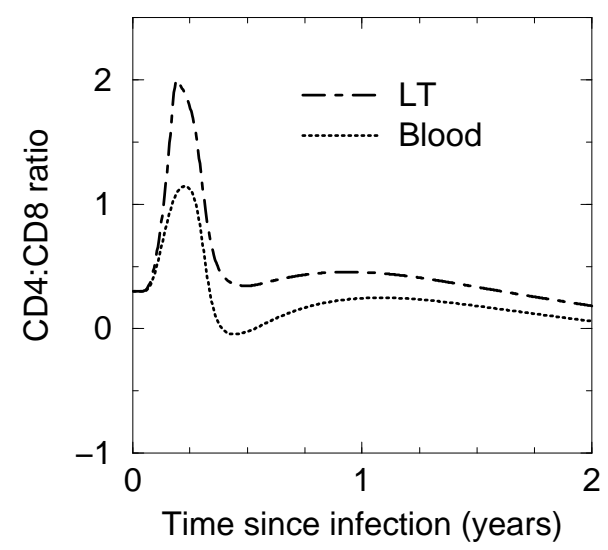

Fig. 2. Acute stage of HIV-1 infection. Panel A: Virus (solid line), CTL (long dashed), and TH (short dashed) dynamics over 2 years post-infection in the LT. Panel B: CD4/CD8 ratio in the blood (dotted) and LT (dot-dashed) over 2 years post-infection.

Our model simulations reflect a rise in CTL number concurrent with a rapid increase in viremia during acute stage of disease (Figure 2, Panel A). CD4 ${ }^{+}$T-cell help and CTL levels initially follow this increase in virus, while for the remainder of disease progression they correlate inversely with viral load (Ogg et al., 1998). We simulate the ratio inversion of CD4 to CD8 from 2 to 0.5 during acute infection; however our results show that there is a slightly lower CD4:CD8 ratio in the blood with a higher ratio in the LT (Figure 2, Panel B). This indicates either a higher number of $\mathrm{CD} 8^{+} \mathrm{T}$ cells or lower numbers of $\mathrm{CD} 4^{+} \mathrm{T}$ cells in the blood as compared to LT, reflecting the skewed distribution of lymphocytes during massive viral infection.

\section{$C D 8^{+} T$ cells in Chronic and End-Stage Infection}

After the acute stage of infection, which occurs over the first few months of infection, resting $\mathrm{CD} 4^{+} \mathrm{T}$-cell, activated $\mathrm{CD} 4^{+} \mathrm{T}$ helper cell, and CTL levels increase and virus decreases to a quasi-steady-state level. This resolution of virus to a quasi-steady-state level, referred to as the viral setpoint, occurs for several years and is characteristic of the chronic stage of disease (Ho et al., 1995). Our simulation shows a quasi-steady-state level of virus in the blood and LT following the acute stage of disease that lasts for several years (Figure 3, Panel A). We also show the typical rebound of resting $\mathrm{CD} 4^{+}$and $\mathrm{CD} 8^{+} \mathrm{T}$ cells to high levels fol- 
lowed by the gradual $\mathrm{CD} 4^{+} \mathrm{T}$-cells decline throughout a typical ten-year disease progression (Figure 3, Panel B).

Resting $\mathrm{CD} 8^{+} \mathrm{T}$ cells decline initially due to massive expansion of the CTL population, but recover to normal levels rapidly and only decrease slightly throughout disease progression (Figure 3, Panel B and (McCune et al., 2000; Hellerstein et al., 1999; Kovacs et al., 2001)). Because there is little to no helper activity in the blood after the acute stage of infection in data (Betts et al., 2001), we are able to examine dynamics of resting and activated $\mathrm{CD} 4^{+}$and $\mathrm{CD} 8^{+} \mathrm{T}$ cells only in LT (Figure 3, Panels C and D).

For comparison, we present clinical data for cell populations and virus in the chronic phase of disease with results from our model simulations (Table 4).

Table 4. Comparison of simulation at year 3 post-infection with clinical data

\begin{tabular}{|c|c|c|c|}
\hline Population & Model Value & Clinical value & Reference \\
\hline Resting $\mathrm{CD}^{+}{ }^{+} \mathrm{T}$ cells in $\mathrm{LT}$ & $7 \times 10^{10}$ & $10^{10}$ cells & 1 \\
\hline Resting $\mathrm{CD}^{+}{ }^{+} \mathrm{T}$ cells in $\mathrm{LT}$ & $8 \times 10^{10}$ & $10^{10}$ cells & 1 \\
\hline Infected cells in LT & $4 \times 10^{9}$ & $10^{10}$ cells & 1 \\
\hline Virions in LT & $9 \times 10^{10}$ & $5 \times 10^{10}$ virions & 1 \\
\hline Activated $\mathrm{CD} 4^{+} \mathrm{T}$ cells in blood & $0.0000007 \%$ & $0.12 \%$ of $\mathrm{CD} 4^{+} \mathrm{T}$ cells & 2 \\
\hline Activated $\mathrm{CD} 8^{+} \mathrm{T}$ cells in blood & $8.8 \%$ & $0.1 \%-10 \%$ of $\mathrm{CD}^{+} \mathrm{T}$ cells & 3 \\
\hline Median DC in blood & 10 cells $/ \mathrm{ml}$ & 7 cells $/ \mathrm{ml}$ & 4 \\
\hline
\end{tabular}

1 (Haase, 1999)

2 (Pitcher et al., 1999)

3 (Ogg et al., 1998; Scott-Algara et al., 2001)

4 (Barron et al., 2003)

Progression to AIDS occurs for a number of reasons, and one key factor is likely the ultimate failure of the CTL response in controlling viral growth and spread. This may occur due to any of the reasons outlined in section 1.4. With our model, we can observe decreased CTL levels with ongoing disease progressions, alterations in cell distributions, and a high number of activated cells with limited function.

We observe CD4 ${ }^{+}$T-cell decline to AIDS-defining levels $\left(<200\right.$ cells $/ \mathrm{mm}^{3}$ of blood) in the latter stage of infection. However, we do not observe an exponential rise in viral load in the blood in the end stage of disease. This could be due to several factors, among them the lack of target cells for infection once resting and activated $\mathrm{CD}^{+} \mathrm{T}$ cells have declined to extremely low levels (Phillips, 1996). Homeostatic mechanisms may bring more uninfected target $\mathrm{CD} 4^{+}$and $\mathrm{CD} 8^{+} \mathrm{T}$ cells from the thymus during infection; however we have not included this effect 

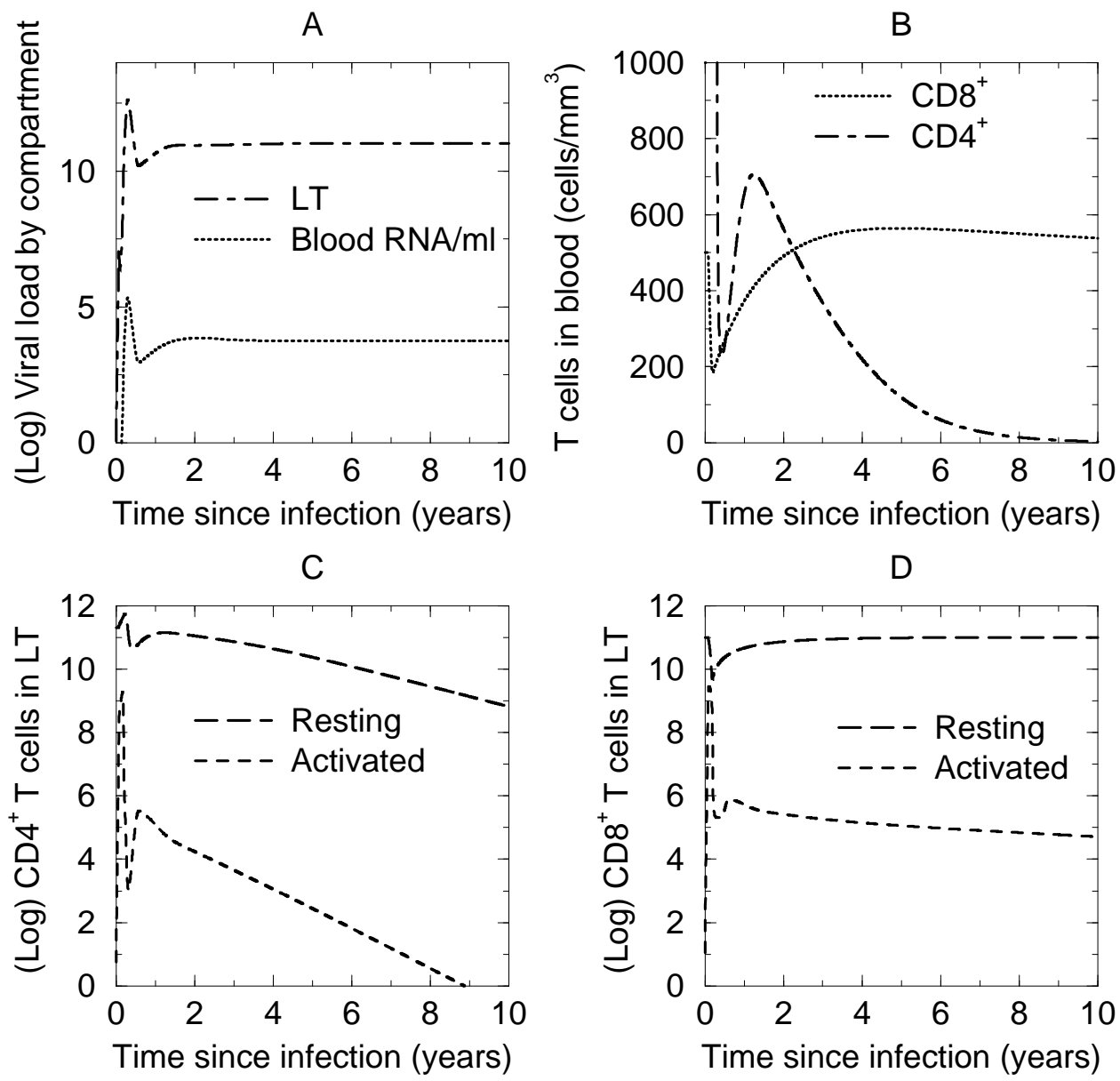

Fig. 3. Three stages of typical HIV-1 disease progression. Shown are simulations of early, chronic, and AIDS stages of disease progression over a 10-year course of infection. Panel A: Virus levels in blood (dotted line) and LT (dot-dashed). Panel B: Total $\mathrm{CD}^{+}$(dot-dashed) and $\mathrm{CD}^{+}$(dotted) T cells in blood. Panel C: Resting (long dashed) and activated (short dashed) $\mathrm{CD}^{+} \mathrm{T}$ cells in LT. Panel D: Resting (long dashed) and activated (short dashed) $\mathrm{CD}^{+} \mathrm{T}$ cells in $\mathrm{LT}$.

as we are solely examining CTL dynamics in the two compartments of blood and lymph tissues.

\subsection{HIV-1-Specific CTL Levels}

Measurement of HIV-1-specific CD8 ${ }^{+}$T-cell responses varies between studies. Specificity for a single peptide is not indicative of the breadth of the CTL response. 
One study that measures specificity by flow cytometric detection of intracellular IFN- $\gamma$, found $1.4-22 \%$ of circulating $\mathrm{CD} 8^{+} \mathrm{T}$ cells to be HIV-1-specific (Migueles and Connors, 2001). Gag, an HIV-1 protein, is most predominantly recognized by CTLs during asymptomatic HIV-1 infection (Johnson et al., 1991; van Baalen et al., 1993). A study that examined the frequency of CTL precursors in response to Gag found them to be in the range of $0.005 \%-0.3 \%$ (Klein et al., 1995). In another study, the gag-specific CD4 ${ }^{+}$T-cell proportion ranged from $0.2 \%$ to $2 \%$ of total $\mathrm{CD} 4^{+} \mathrm{T}$ cells with a mean of $1 \%$. HIV-1-specific CD8 ${ }^{+} \mathrm{T}$ cells ranged from $0.1 \%$ to $5 \%$ with a mean of $3 \%$ (Sester et al., 2000). In that study, it was found that the frequency of HIV-1-specific $\mathrm{CD} 8^{+} \mathrm{T}$ cells was typically higher than that of HIV-1-specific CD4 ${ }^{+} \mathrm{T}$ cells. In general, as much as $10 \%$ of the CD8 ${ }^{+} \mathrm{T}$-cell population could be activated against HIV-1 antigens (Pantaleo et al., 1997a). In Table 5 we present variations in specificity of $\mathrm{CD} 4^{+}$and $\mathrm{CD} 8^{+} \mathrm{T}$ cells concomitant with disease progression based on our model simulations.

Table 5. HIV-1-specific $T$ cells in three stages in our model simulations

\begin{tabular}{cccc}
\hline Cell type & Acute (50 days) & Chronic (3 years) & AIDS (10 years) \\
\hline $\mathrm{CD}^{+}$helper T cells in blood & $0.009 \%$ & $0.0000007 \%$ & $0.000000003 \%$ \\
$\mathrm{CD}^{+}$cytotoxic T cells in blood & $35 \%$ & $8.8 \%$ & $1.1 \%$ \\
\hline
\end{tabular}

We see that there are extremely low percentages of activated $\mathrm{CD} 4^{+} \mathrm{T}$ cells in blood. We need to examine LT dynamics (Figure 3, Panel C) to observe the existence of $\mathrm{CD}^{+}$T-helper cell activity, though it is undetectable in the blood compartment. CTLs however are greater in number than $\mathrm{CD} 4^{+} \mathrm{T}$ helper cells, but also diminish throughout disease progression (Figure 3, Panel D).

\subsection{HIV-1-Specific CTL Action}

It is not known whether CTL killing or inhibition is more influential in disease progression, or whether or not a significant reduction in one or more of these mechanisms would have an impact on cell or viral dynamics. We vary those parameters that impact CTL action on viral infection and production (half-saturation constants on $k_{1}$ through $k_{4}$ and $N$ ). From these results (Table 6), we can see that infection via cell-cell interactions mediated by DCs $\left(c_{2}\right.$ and $\left.c_{4}\right)$ has a larger impact than infection by free virus $\left(c_{1}\right.$ and $\left.c_{3}\right)$ for both resting and activated $\mathrm{CD} 4^{+}$ T-cell infection. Our results show that a 100 -fold change in inhibition of cellmediated infection yields significant changes in disease progression, as compared to a 10000 -fold change on inhibition of virus infection necessary to significantly affect the results. Interestingly, changing the infection rate of activated $\mathrm{CD} 4^{+} \mathrm{T}$ cells by virus is not affected significantly by CTLs. Activated cells may not contribute significantly to the infected cell class due to their extremely short half-life. 
Additionally, the interaction between $\mathrm{T}$ helper cells and DCs could be far more influential in the infection process than the effect of free virus to $\mathrm{T}$ helper cells.

Table 6. Effects of variations in CTL activity on disease dynamics

\begin{tabular}{ccc}
\hline Parameter & Fold change & Results \\
\hline Inhibition & & \\
Viral infection of resting CD $4^{+} \mathrm{T}$ cells $\left(c_{1}\right)$ & $\downarrow 10000$ & delayed acute stage \\
DC infection of resting CD $4^{+} \mathrm{T}$ cells $\left(c_{2}\right)$ & $\downarrow 100$ & $\uparrow$ resting CD $4^{+} \mathrm{T}$ cells \\
Viral infection of activated CD $4^{+} \mathrm{T}$ cells $\left(c_{3}\right)$ & $\downarrow 10000$ & no significant change \\
DC infection of activated CD4 ${ }^{+} \mathrm{T}$ cells $\left(c_{4}\right)$ & $\downarrow 100$ & delayed acute stage \\
Virus production by infected cells $\left(c_{5}\right)$ & $\downarrow 10$ & delayed acute stage \\
Killing & & \\
Infected cells by CTLs $(\kappa)$ & $\uparrow 100$ & lower viral setpoint \\
\hline
\end{tabular}

It is important to note that CTLs do not prevent infection, but only alter disease dynamics, i.e. the establishment of the acute stage of infection or the viral setpoint. Likely other cell types (such as those involved in innate immunity) or mutation in coreceptors (such as the CCR $5 \Delta 32$ deletion) may play a role in the possible elimination of or resistance to initial virus introduced into the host.

\subsection{CD4 ${ }^{+} \mathrm{T}$ Helper Cells and Dendritic Cells Work Together to Yield a Successful CTL Response}

One key hypothesis for the failing CTL response is the declining role of $\mathrm{CD} 4^{+}$ T-cell help to $\mathrm{CD} 8^{+} \mathrm{T}$-cell action. $\mathrm{CD} 4^{+} \mathrm{T}$ cells both activate and give instructional signals to CD8 ${ }^{+} \mathrm{T}$ cells during priming of CTLs. Low levels of help early in infection are attributed to a highly non-specific $\mathrm{CD} 8^{+} \mathrm{T}$-cell response, which is ineffective for long-term immune control (McMichael and Rowland-Jones, 2001; Brodie et al., 1999; Kalams and Walker, 1998). We explore the effects of both an increase or decrease in activation of $\mathrm{CD} 4^{+} \mathrm{T}$ cells into $\mathrm{CD} 4^{+} \mathrm{T}$ helper cells (parameter $r$ in Equation 1). Our simulations show that higher CD4 ${ }^{+}$T-cell numbers correlate with higher CTL levels (Figure 4). Additionally, increased activation, although decreasing numbers of resting $\mathrm{CD} 4^{+}$and $\mathrm{CD} 8^{+} \mathrm{T}$ cells, results in a higher total number of $\mathrm{CD} 4^{+} \mathrm{T}$ cells in the blood (Figure 4, Panel A) and a higher level of CTLs in the LT (Figure 4, Panel B). This follows from our assumption that increased $\mathrm{CD} 4^{+} \mathrm{T}$ helper cells activate $\mathrm{DCs}$ and $\mathrm{CD} 8^{+} \mathrm{T}$ cells early enough to prevent further $\mathrm{CD} 4^{+} \mathrm{T}$-cell loss, as is observed during acute infection.

The interaction between resting $\mathrm{CD} 4^{+} \mathrm{T}$ cells and MDCs in the LT can result in the development of $\mathrm{CD} 4^{+} \mathrm{T}$ helper cells and dendritic cells with $\mathrm{CD} 8^{+} \mathrm{T}$-cell priming capability. Thus, the differentiation of $\mathrm{CD} 8^{+} \mathrm{T}$ cells to HIV-1-specific CTLs can occur either through $\mathrm{CD} 8^{+} \mathrm{T}$ cells coming into contact directly with 
A

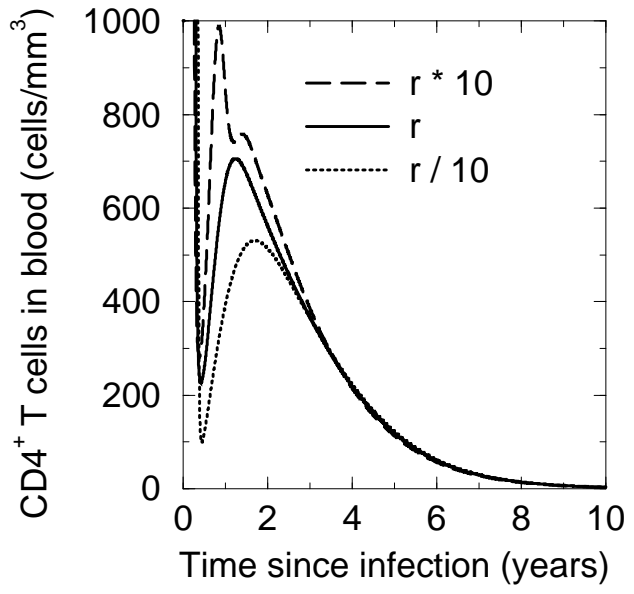

B

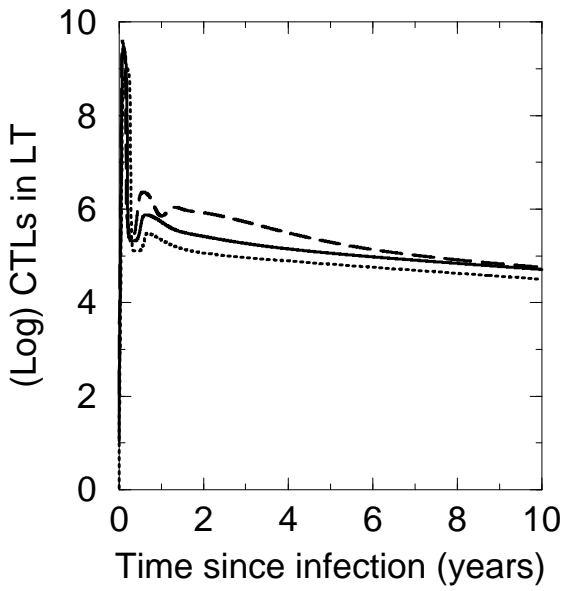

Fig. 4. $\mathrm{CD}^{+}$and $\mathrm{CD8}^{+} \mathrm{T}$ cell levels vary with activation rate, $r$. Shown is a simulation of $\mathrm{CD}^{+} \mathrm{T}$ cells in the blood (Panel A) and CTLs in the LT (Panel B) with respect to the rate of activation of resting $\mathrm{CD} 4^{+} \mathrm{T}$ cells by MDCs in the LT (parameter $r$ in Equation 1).

$\mathrm{CD}^{+} \mathrm{T}$ helper cells or through contact with dendritic cells. However, to distinguish between contact with any MDCs and those that have received activation signals from a CD4 ${ }^{+} \mathrm{T}$ cells, the equation for differentiation via dendritic cells includes augmentation by $\mathrm{CD} 4^{+} \mathrm{T}$-cell help (which saturates at $f_{3}$ ). To examine whether the dendritic cell-differentiation pathway or the direct $\mathrm{CD} 4^{+}-\mathrm{CD} 8^{+} \mathrm{T}$ cell-activation pathway is more significant, we vary the differentiation parameters $\chi_{D}$ and $\chi_{T}$, respectively, and examine effects to the total production of CTLs in the LT (Figure 5). We find that differentiation of $\mathrm{CD} 8^{+} \mathrm{T}$ cells by meeting $\mathrm{CD}^{+} \mathrm{T}$ cells directly is more significant than by meeting MDCs (augmented by help), and speculate that dendritic cells may be more crucial in the activation of HIV-1-specific CD4 ${ }^{+}$T helper cells than the activation of HIV-1-specific CTLs.

There is conflicting information as to numbers or proportions of blood dendritic cells in HIV-1 infected individuals. There is evidence that DCs are depleted in the blood early in HIV-1 infection, corresponding with an increase in blood viral levels (Donaghy et al., 2001; Feldman et al., 2001; Pacanowski et al., 2001; Grassi et al., 1999). This loss could be attributed to a down-regulation of DC markers in the blood, a decrease in new cells input from the bone marrow (Pacanowski et al., 2001), enhanced DC deletion or death, or a rapid export of DCs into the lymph tissues (Cyster, 1999; Lore et al., 2002). Support for migration of mature DCs to T-cell rich areas in the LT comes from studies of selective recruitment of DCs by chemokines to sites of infection (Dieu et al., 1998; Foti et al., 1999). 
A

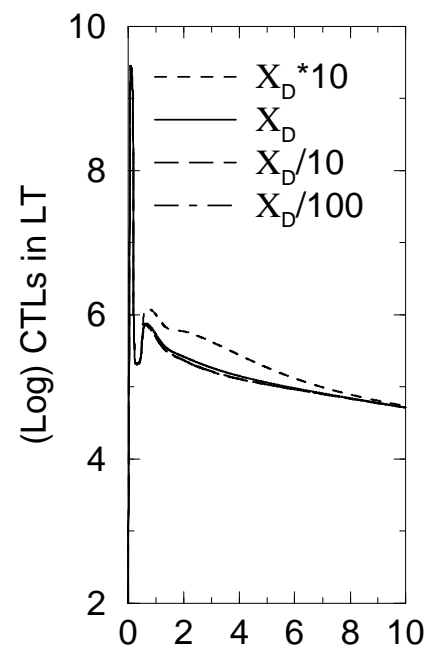

B

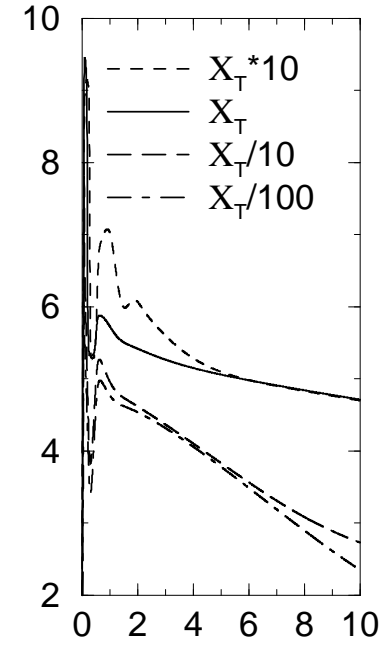

C

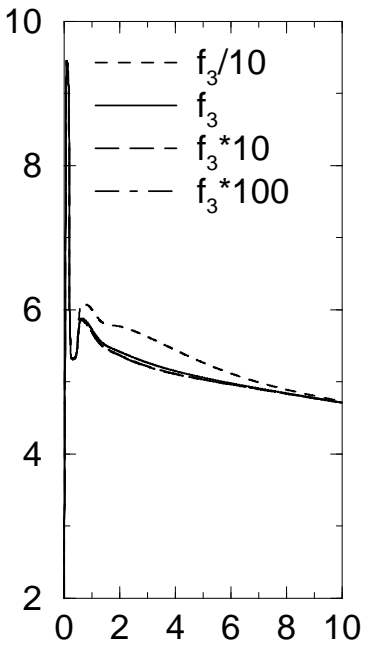

Time since infection (years)

Fig. 5. Success of CTL priming by MDCs and $\mathbf{T}$ helper cells. Shown is a simulation of CTL levels in the LT based on changes in the differentiation rate of resting $\mathrm{CD}^{+} \mathrm{T}$ cells by dendritic cells, $\chi_{D}$, (Panel A), the differentiation rate of resting $\mathrm{CD} 8^{+}$ $\mathrm{T}$ cells by $\mathrm{CD} 4^{+} \mathrm{T}$ helper cells, $\chi_{T}$, (Panel B), and half-saturation for $\mathrm{CD} 4{ }^{+} \mathrm{T}$-cell help to $\mathrm{CD}^{+}$T-cell differentiation, $f_{3}$ (Panel C) from Eqns. 8 and 10). We vary these parameters over an order of magnitude range encompassing baseline values and observe effects to the time progression of CTLs.

Our model does not account for differences between the plasmacytoid DC class and the myeloid DCs. These subsets are distinguished based on their phenotype and function during HIV-1 infection and these will be explored in future work. However, both subsets are depleted in the blood during infection to approximately half of their original values in therapy-naive patients (Barron et al., 2003) and our model reflects that deficiency in the blood compartment (see Figure 6, Panel A). This decrease in blood DCs has also been shown to have a strong correlation with viral load (Donaghy et al., 2001). A rapid influx of DCs into LT is observed in acute infection, as shown in Figure 6, Panel B and described in (Lore et al., 2002). The specific mechanisms of DC trafficking into and out of the LT are considered in other work (in preparation).

In this work, we assume that the heightened state of immune activation during infection reported in several studies (Hazenberg et al., 2003b,a; Leng et al., 2001; Papagno et al., 2004) can be captured by enhanced recruitment of DCs into the LT due to virus. Because dendritic cells are the primary activators of both resting $\mathrm{CD} 4^{+}$and $\mathrm{CD} 8^{+} \mathrm{T}$ cells in our model, this assumption mimics in- 
A

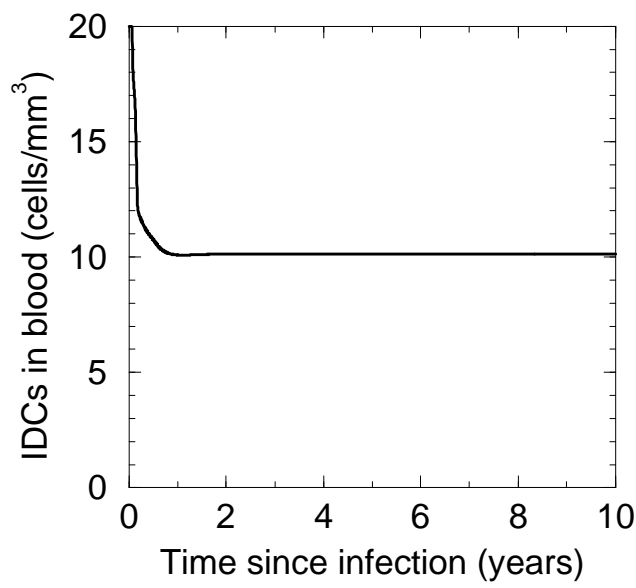

B

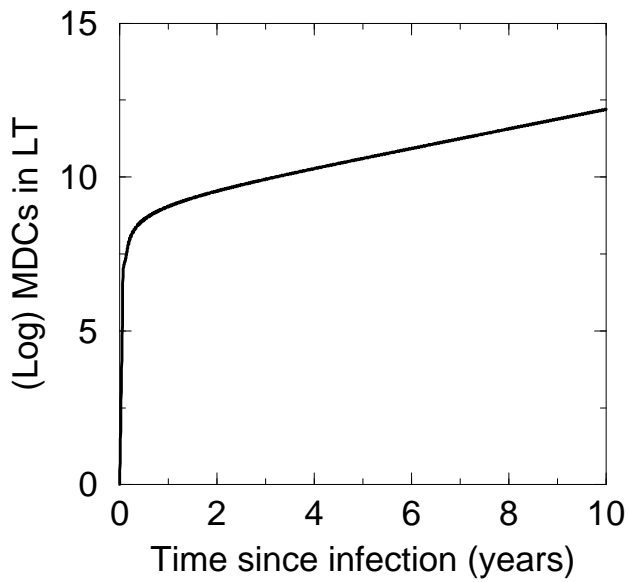

Fig. 6. Dendritic cell dynamics. Shown is a simulation of immature DCs (IDCs) in the blood (Panel A) and mature DCs (MDCs) in the LT (Panel B) over the course of a typical 10-year disease progression.

creased immune activation during the course of infection. To explore the role of priming, we study immune activation and activated T-cell levels in Figure 7. We observe that for less activation (due to no recruitment of MDCs into LT with increasing viral levels), $\mathrm{CD} 4^{+} \mathrm{T}$ cells in blood remain elevated similar to that of a long-term non-progressor (Zhang et al., 1997). With higher than baseline immune activation (excessive recruitment of MDCs into LT), there is a rapid decline in the CD4 ${ }^{+}$T-cell count (Figure 7, Panel B). Finally, even though activated T-cell levels fall greatly after the acute stage, our simulation shows their numbers remain steady in the LT when immune activation is low and fall more rapidly when immune activation is excessive (Figure 7, Panel C). Some groups have suggested that HIV-specific CTL might become exhausted through telomere shortening during constant divison resulting from chronic immune activation (Wodarz et al., 1998; Effros et al., 1996). Many studies have suggested that chronic immune activation may be a better predictor of disease progression than viral load (Simmonds et al., 1991; Leng et al., 2001; Roussanov et al., 2000; Giorgi et al., 1999) and our simualtions concur (based on more rapid $\mathrm{CD} 4^{+} \mathrm{T}$-cell decline with increased immune activation).

\section{CONCLUSIONS AND DISCUSSION}

Several groups have considered the role of CTLs in HIV-1 infection using mathematical models (Wodarz et al., 1998; Ribeiro et al., 2002; Antia et al., 2003; Wick 

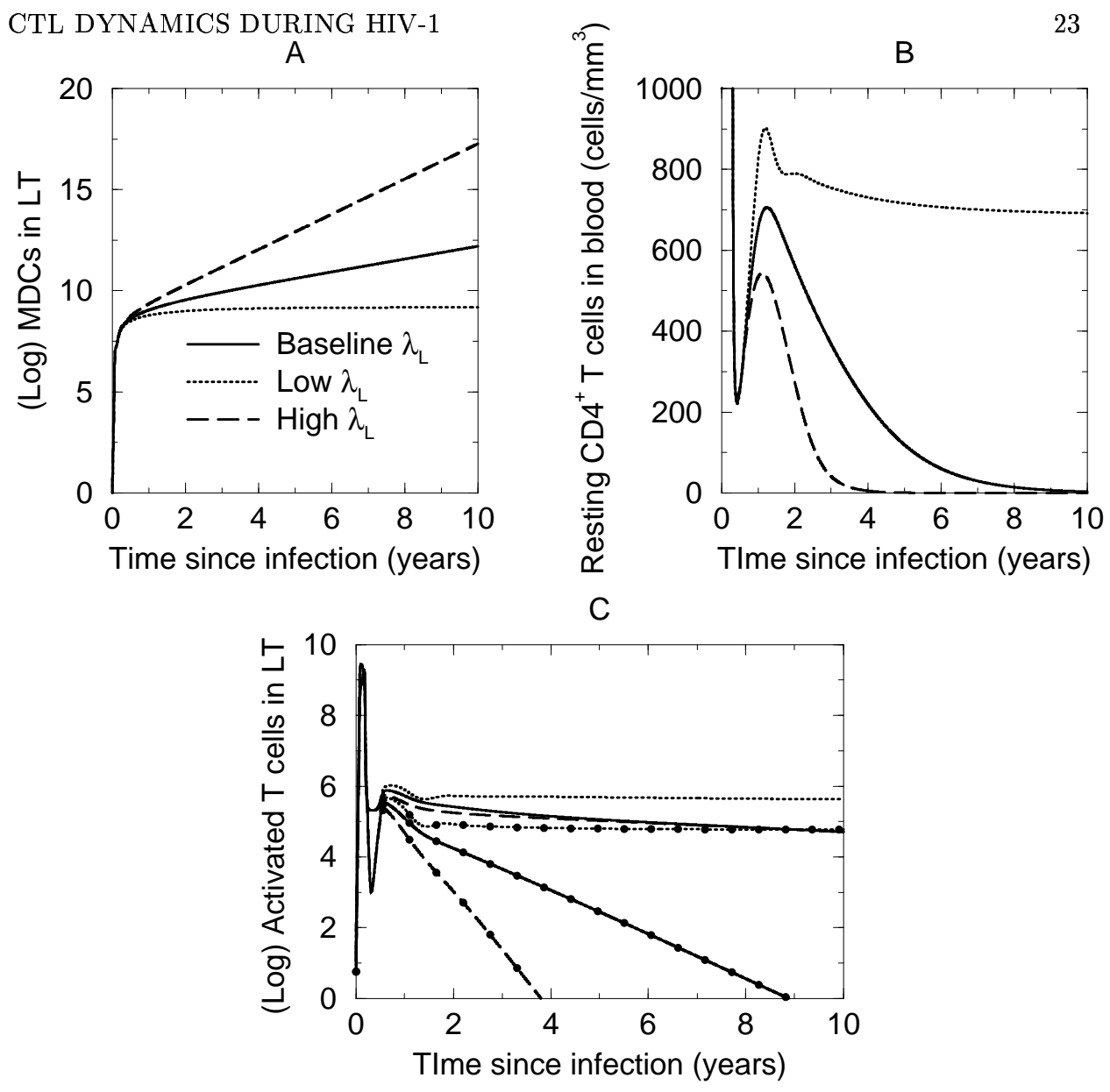

Fig. 7. Changes in time to AIDS based on immune activation status. Here, immune activation is captured by the rate of recruitment of DCs into the LT (Parameter $\lambda_{L}$ in Eqn. 12). We vary this parameter above (increased activation, $\lambda_{L}=.0105$ ) and below (decreased activation, $\left.\lambda_{L}=.0035\right)$ the baseline value $\left(\lambda_{L}=.007\right)$ to observe effects. Panel A shows changes to levels of DCs in LT and Panel B shows changes to blood $\mathrm{CD}^{+} \mathrm{T}$ cell counts for these three scenarios. In Panel C, we show levels of activated $\mathrm{T}$ cells in the LT (i.e., $\mathrm{CD} 4^{+}$(filled circles) and $\mathrm{CD} 8^{+} \mathrm{T}$ cells (lines only), respectively). We observe a more rapid decline in HIV-1-specific T helper cells and CTLs with increasing immune activation.

and Self, 2002; Arnaout et al., 2000; Fraser et al., 2002), and others the role of CD4 ${ }^{+}$T-cell help to CTL responses (Wodarz and Jansen, 2001; Wodarz, 2001). Our work expands on these ideas in many ways. First, we study lymphocyte circulation in health and disease with the use of a two-compartment model and are able to incorporate important dynamics of lymphocyte circulation as well as defects 
imposed on circulation by HIV-1 infection. Additionally, we include the specific roles of dendritic cells as antigen-presenting cells and their numbers and functional properties in antigen uptake as well as presentation to $\mathrm{CD} 4^{+}$and $\mathrm{CD} 8^{+} \mathrm{T}$ cells in blood and LT. We consider the total lymph system and use biologically relevant parameter estimations derived from literature, and our simulations compare with clinical and experimental data during various stages of disease progression.

Our simulations reflect the three-stage disease course in a typical HIV-1 progressor with gradually declining $\mathrm{CD} 4^{+} \mathrm{T}$-cell levels throughout the chronic phase of disease ((Collaboration, 2003) and Figure 3, Panel B). We use this positive control to test variations in $\mathrm{CD} 4^{+} \mathrm{T}$-cell help and $\mathrm{DC}$ activation to the successful differentiation of $\mathrm{CD} 8^{+} \mathrm{T}$ cells to CTLs. In this context, we find that $\mathrm{CD} 4^{+} \mathrm{T}$-cell help is necessary for the priming of CTLs, and that interaction of $\mathrm{CD} 8^{+} \mathrm{T}$ cells with both $\mathrm{CD}^{+} \mathrm{T}$ cells and DCs is crucial for successful CTL development and actions during HIV-1 infection.

There is evidence that inadequately developed $\mathrm{CD} 8^{+} \mathrm{T}$ cells lack the capacity to effectively control HIV-1 infection, especially as disease progresses (Champagne et al., 2001). It is thought that CD4 ${ }^{+}$T-cell help may function in the memory $\mathrm{CD} 8^{+}$T-cell response during recurring episodes of virus growth throughout the chronic phase of infection (Kaech and Ahmed, 2003; Janssen et al., 2003; Sun and Bevan, 2003; Shedlock and Shen, 2003; Bourgeois et al., 2002). However, in some experimental systems, CD4 ${ }^{+}$T-cell help is also essential for the primary response (Wang and Livingstone, 2003). This model does not examine the development of a memory response. However, the development of activated CTLs does decline concommitant with the decline in $\mathrm{CD} 4^{+} \mathrm{T}$-cell help, and so we expect that there would also be a proportional decrease in memory $\mathrm{CD} 8^{+} \mathrm{T}$ cells available for a recall response.

It has been suggested that the activity of IL-2 is necessary for perforin expression due to high, early perforin expression in infection that declines with disease progression (Zhang et al., 2003). However, we tested the effect of reducing CTL killing of infected cells based on levels of $\mathrm{CD}^{+} \mathrm{T}$ helper cells in the system (which are the main producers of IL-2) and found little to no variation in outcome (data not shown). This could be due to our assumption accounting only for HIV-1-specific CTLs, which have been shown to be generally deficient in perforin, and only a percentage successfully migrate to the LT for cytotoxic activities (Chen et al., 2001). Therefore, as our model simulations show, it is important to consider the unique properties of HIV-1-specific CTLs to be able to study their dysfunctions during disease progression.

HIV-1 has evolved several properties to intervene in normal immune system functioning. For example, the HIV-1 envelope protein Nef interferes with the antigen-presentation pathway by intersecting the CD40-CD40L pathway of dendritic cell activation (Pope, 2003; Andrieu et al., 2001). This may result in impaired activation of dendritic cells that would render them inefficient at antigen presenta- 
tion. However, dendritic cells and $\mathrm{T}$ cells are in close contact during infection, and the proximity of dendritic cell-associated virus to $\mathrm{T}$ cells will render $\mathrm{T}$ cells highly susceptible to cell-associated infection. Thus, activation levels of dendritic cells become important when determining under which circumstances dendritic cells result in either activation or in $\mathrm{CD} 4^{+}$T-cell infection (Lutz and Schuler, 2002; $\mathrm{McDonald}$ et al., 2003). Inadequate signaling may be deleterious to the system, and the role of dendritic cells in HIV-1 infection requires further study.

This work has examined the dynamics of CTLs in HIV-1 infection. Our simulations indicate that activation of $\mathrm{CD} 4^{+} \mathrm{T}$ cells by $\mathrm{DCs}$ and activation of $\mathrm{CD} 8^{+}$ $\mathrm{T}$ cells by both $\mathrm{CD}^{+} \mathrm{T}$ cells and $\mathrm{DCs}$ is crucial in infection. Thus, although CTLs cannot be the sole determinant in disease outcome, they are significant contributors to dynamics influencing disease progression.

\section{ACKNOWLEDGEMENTS}

This work was supported by National Institutes of Health Grant HL62119 and HL72682.

\section{References}

Albert, M., Sauter, B., and Bhardwaj, N. (1998). Dendritic cells acquire antigen from apoptotic cells and induce class I-restricted CTLs. Nature, 392:86-89.

Andersson, J., Behbahani, H., and Lieberman, J. (1999). Perforin is not coexpressed with granzyme A within cytotoxic granules in CD8 T lymphocytes present in lymphoid tissue during chronic HIV infection. AIDS, 13:1295-1303.

Andersson, J., Kinloch, S., Sonnerborg, A., Nilsson, J., Fehniger, T., Spetz, A., Behbahani, H., Goh, L., McDade, H., Gazzard, B., Stellbrink, H., Cooper, D., and Perrin, L. (2002). Low levels of perforin expression in CD8+ T lymphocyte granules in lymphoid tissue during acute immunodeficiency virus type 1 infection. $J$ Infect Dis, 185:1355-1358.

Andrieu, M., Chassin, D., Desoutter, J., Bouchaert, I., Baillet, M., Hanau, D., Guillet, J., and Hosmalin, A. (2001). Downregulation of major histocompatibility class I on human dendritic cells by HIV Nef impairs antigen presentation to HIV-specific CD8+ T lymphocytes. AIDS Res Hum Retroviruses, 17:1365-1370.

Antia, R., Bergstrom, C., Pilyugin, S., Kaech, S., and Ahmed, R. (2003). Models of CD8+ responses: 1 . What is the antigen-independent proliferation program. $J$ Theor Biol, 221:585-598.

Appay, V., Dunbar, P., Callan, M., Klenerman, P., Gillespie, G., Papagno, L., Ogg, G., King, A., Lechner, F., Spina, C., Little, S., Havlir, D., Richman, D., Gruener, N., Pape, G., Waters, A., Easterbrook, P., Salio, M., Cerundolo, V., McMichael, A., and Rowland-Jones, S. (2002). Memory CD8+ T cells vary 
in differentiation phenotype in different persistent virus infections. Nat Med, 8:379-385.

Appay, V., Nixon, D., Donahoe, S., Gillespie, G., Dong, T., King, A., Ogg, G., Spiegel, H., Conlon, C., Spina, C., Havlir, D., Richman, D., Waters, A., Easterbrook, P., McMichael, A., and Rowland-Jones, S. (2000). HIV-specific CD8 ${ }^{+}$T cells produce antiviral cytokines but are impaired in cytolytic function. $J$ Exp Med, 192:63-75.

Arnaout, R., Nowak, M., and Wodarz, D. (2000). HIV-1 dynamics revisited: biphasic decay of cytotoxic T lymphocyte killing? Proc $R$ Soc Lond B, 267:13471354.

Auphan-Anezin, N., Verdeil, G., and Schmitt-Verhulst, A.-M. (2003). Distinct thresholds for CD8 $\mathrm{T}$ cell activation lead to functional heterogeneity: CD8 T cell priming can occur independently of cell division. J Immunol, 170:2442-2448.

Bajaria, S., Webb, G., Cloyd, M., and Kirschner, D. (2002). Dynamics of naive and memory $\mathrm{CD}^{+} \mathrm{T}$ lymphocytes in HIV-1 disease progression. $J$ Acquir Immune Deficiency Syndromes, 30:41-58.

Banchereau, J. and Steinman, R. (1998). Dendritic cells and the control of immunity. Nature, 392:245-252.

Baribaud, F., Pohlmann, S., and Doms, R. (2001). The role of DC-SIGN and DC-SIGNR in HIV and SIV attachment, infection, and transmission. Virology, 286:1-6.

Barker, E., Bossart, K., and Levy, J. (1998). Primary CD8 ${ }^{+}$cells from HIVinfected individuals can suppress productive infection of macrophages independent of $\beta$-chemokines. Proc Natl Acad Sci, 95:1725-1729.

Barron, M., Blyveis, N., Palmer, B., MaWhinney, S., and Wilson, C. (2003). Influence of plasma viremia on defects in number and immunophenotype of blood dendritic cell subsets in human immunodeficiency virus 1-infected individuals. J Infect Dis, 187:26-37.

Bennett, S., Carbone, F., Karamalis, F., Flavell, R., Miller, J., and Heath, W. (1998). Help for cytotoxic-T-cell responses is mediated by CD40 signalling. Nature, 393:478.

Berke, G. (1995). The CTLs kiss of death. Cell, 81:9-12.

Betts, M., Ambrozak, D., Douek, D., Bonhoeffer, S., Brenchley, J., Casazza, J., Koup, R., and Picker, L. (2001). Analysis of total human immunodeficiency virus (HIV)-specific CD4+ and CD8+ T-cell responses : relationship to viral load in untreated HIV infection. $J$ Virol, 75:11983-11991.

Blower, S. and Dowlatabadi, H. (1994). Sensitivity and uncertainty analysis of complex models of disease transmission: an HIV model, as an example. Int Stat Rev, 62:229-243.

Borrow, P. (1994). Virus-specific CD8+ cytotoxic T-lymphocyte activity associated with control of viremia in primary human immunodeficiency virus type 1 infection. $J$ Virol, 68:6103-6110. 
Bottomly, K. (1999). T cells and dendritic cells get intimate. Science, 283:11241125.

Bourgeois, C., Rocha, B., and Tanchot, C. (2002). A role for CD40 expression on CD8+ T cells in the generation of CD8+ T cell memory. Science, 297:20602063.

Bousso, P. and Robey, E. (2003). Dynamics of CD $8^{+} \mathrm{T}$ cell priming by dendritic cells in intact lymph nodes. Nat Immunol, 4:579-585.

Brodie, S., Lewinsohn, D., Patterson, B., Jiyamapa, D., Krieger, J., Corey, L., Greenberg, P., and Riddell, S. (1999). In vivo migration and function of transferred HIV-1-specific cytotoxic T cells. Nat Med, 5:34-41.

Buseyne, F., Le Gail, S., Boccaccio, C., Abastado, J.-P., Lifson, J., Arthur, L., Riviere, Y., Heard, J.-M., and Schwartz, O. (2001). MHC-1-restricted presentation of HIV-1 virion antigens without viral replication. Nat Med, 7:344-349.

Caruso, A., Licenziati, S., Canaris, A., Cantalamessa, A., Fiorentini, S., Ausenda, S., Ricotta, D., Dima, F., Malacarne, F., Balsari, A., and Turano, A. (1998). Contribution of CD4+, CD8+CD28+, and CD8+CD28- T cells to CD3+ lymphocyte homeostasis during the natural course of HIV-1 infection. J Clin Invest, 101:137-144.

Caux, C., Massacrier, C., Vanbervliet, B., Dubois, B., Van Kooten, C., Durand, I., and Bancherau, J. (1994). Activation of human dendritic cells through CD40 cross-linking. J Exp Med, 180:1263.

Cavert, W., Notermans, D., Staskus, K., Wietgrefe, S., Zupancic, M., Gebhard, K., Henry, K., Zhang, Z., Mills, E., McDade, H., Schuwirth, C., Goudsmit, J., Danner, S., and Haase, A. (1997). Kinetics of response in lymphoid tissues to antiretroviral therapy of HIV-1 infection. Science, 276:960-964.

Cella, M., Engering, A., Pinet, V., Pieters, J., and Lanzavecchia, A. (1997). Inflammatory stimuli induce accumulation of MHC class II complexes on dendritic cells. Nature, 388:782-787.

Cella, M., Scheidegger, D., Palmer-Lehmann, K., Lane, P., Lanzavecchia, A., and Alber, G. (1996). Ligation of CD40 on dendritic cells triggers production of high levels of interleukin-12 and enhances T cell stimulatory capacity: T-T help via APC activation. J Exp Med, 184:747-752.

Champagne, P., Ogg, G., King, A., Knabenhans, C., Ellefsen, K., Nobile, M., Appay, V., Paolo Rizzardi, G., Fleury, S., Lipp, M., Forster, R., Rowland-Jones, S., Sekaly, R.-P., McMichael, A., and Pantaleo, G. (2001). Skewed maturation of memory HIV-specific CD8 T lymphocytes. Nature, 410:106-111.

Chang, T., Francois, F., Mosoian, A., and Klotman, M. (2003). CAF-mediated human immunodeficiency virus (HIV) type 1 transcriptional inhibition is distinct from alpha-defensin-1 HIV inhibition. $J$ Virol, 77:6777-6784.

Chen, G., Shankar, P., Lange, C., Valdez, H., Skolnik, P., Wu, L., Manjunath, N., and Lieberman, J. (2001). CD8 T cells specific for human immunodeficiency 
virus, Epstein-Barr virus, and cytomegalovirus lack molecules for homing to lymphoid sites of infection. Blood, 98:156-164.

Cocchi, F. (1995). Identification of RANTES, MIP- $1 \alpha$, and MIP- $1 \beta$ as the major HIV-suppressive factors produced by CD ${ }^{+}$T cells. Science, 270:1811-1815.

Collaboration, C. (2003). Differences in CD4 cell counts at seroconversion and decline among 5739 HIV-1-infected individuals with well-estimated dates of seroconversion. J Acquir Immune Defic Syndr, 34:76-83.

Curtis, B., Scharnowske, S., and Watson, A. (1992). Sequence and expression of a membrane-associated C-type lectin that exhibits CD4-independent binding of human immunodeficiency virus enevlope glycoprotein gp120. Proc Natl Acad Sci, 89:8356-8360.

Cyster, J. (1999). Chemokines and cell migration in secondary lymphoid organs. Science, 286:2098-2102.

Dieu, M.-C., Vanbervliet, B., Vicari, A., Bridon, J.-M., Oldham, E., Ait-Yahia, S., Briere, F., Zlotnik, A., Lebecque, S., and Caux, C. (1998). Selective recruitment of immature and mature dendritic cells by distinct chemokines expressed in different anatomic sites. J Exp Med, 188:373-386.

Donaghy, H., Pozniak, A., Gazzard, B., Qazi, N., Gilmour, J., Gotch, F., and Patterson, S. (2001). Loss of blood CD11 $\mathrm{c}^{+}$myeloid and CD11c ${ }^{-}$plasmacytoid dendritic cells in patients with HIV-1 infection correlates with HIV-1 RNA virus load. Blood, 98:2574-2576.

Douek, D. (1998). Changes in thymic function with age and during the treatment of HIV infection. Nature, 396:690-695.

Douek, D., Brenchley, J., Betts, M., Ambrozak, D., Hill, B., Okamoto, Y., Casazza, J., Kuruppu, J., Kunstman, K., Wolinsky, S., Grossmna, Z., Dybul, M., Oxenius, A., Price, D., Connors, M., and Koup, R. (2002). HIV preferentially infects HIV-specific CD4+ T cells. Nature, 417:95-98.

Effros, R., Allsopp, R., Chiu, C., Hausner, M., Hirji, K., Wang, L., Harley, C., Villeponteau, B., West, M., and Giorgi, J. (1996). Shortened telomeres in the expanded CD28-CD8+ cell subset in HIV disease implicate replicative senescence in HIV pathogenesis. AIDS, 10:F17-22.

Ellefsen, K., Harari, A., Champagne, P., Bart, P., Sekaly, R., and Pantaleo, G. (2002). Distribution and functional analysis of memory antiviral CD8 T cell responses in HIV-1 and cytomegalovirus infections. Eur J Immunol, 32:37563764 .

Emilie, D., Maillot, M., Nicolas, J., Fior, R., and Galanaud, P. (1992). Antagonistic effect of interferon-gamma on tat-induced transactivation of HIV long terminal repeat. J Biol Chem, 267:20565-20570.

Engering, A., van Vliet, S., Geijtenbeek, T., and van Kooyk, Y. (2002). Subset of DC-SIGN $^{+}$dendritic cells in human blood transmits HIV-1 to T lymphocytes. Blood, 100:1780-1786. 
Feldman, S., Stein, D., Amrute, S., Denny, T., Garcia, Z., Kloser, P., Sun, Y., Megjugorac, N., and Fitzgerald-Bocarsly, P. (2001). Decreased interferon-alpha production in HIV-infected patients correlates with numerical and functional deficiencies in circulating type 2 dendritic cell precursors. Clin Immunol, 101:201210.

Ferbas, J., Giorgi, J., and Amini, S. (2000). Antigen-specific production of RANTES, macrophage inflammatory protein (MIP)- $1 \alpha$, and (MIP)- $1 \beta$ in vitro is a correlate of reduced human immunodeficiency virus burden in vivo. $J$ Infect Dis, 182:1247-1250.

Folkvord, J., Anderson, D., Arya, J., MaWhinney, S., and Connick, E. (2003). Microanatomic relationships between $\mathrm{CD} 8^{+}$cells and HIV-1-producing cells in human lymphoid tissue in vivo. J Acquir Immune Defic Syndr, 32:469-476.

Fong, L., Mengozzi, M., Abbey, N., Herndier, B., and Engleman, E. (2002). Productive infection of plasmacytoid dendritic cells with human immunodeficiency virus type 1 is triggered by CD40 ligation. $J$ Virol, 76:11033-11041.

Forster, R., Schubel, A., Breitfeld, D., Kremmer, E., Renner-Muller, I., Wolf, E., and Lipp, M. (1999). CCR7 coordinates the primary immune response by establishing functional microenvironments in secondary lymphoid organs. Cell, 99:23-33.

Foti, M., Granucci, F., Aggujaro, D., Liboi, E., Luini, W., Minardi, S., Mantovani, A., Sozzani, S., and Ricciardi-Castagnoli, P. (1999). Upon dendritic cell (DC) activation chemokines and chemokine receptor expression are rapidly regulated for recruitment and maintenence of DC at the inflammatory site. Int Immunol, 11:979-986.

Fraser, C., Ferguson, N., de Wolf, F., Ghani, A., Garnett, G., and Anderson, R. (2002). Antigen-driven T-cell turnover. J Theor Biol, 219:177-192.

Geijtenbeek, T., Kwon, D., Torensma, R., van Vliet, S., van Duijnhoven, G., Middel, J., Cornelissen, I., Nottet, H., KewalRamani, V., Littman, D., Figdor, C., and van Kooyk, Y. (2000). DC-SIGN, a dendritic cell specific HIV-1 binding protein that enhances trans-infection of T cells. Cell, 100:587-597.

Gillespie, G., Wils, M., Appay, V., O'Callaghan, C., Murphy, M., Smith, N., Sissons, P., Rowland-Jones, S., Bell, J., and Moss, P. (2000). Functional heterogeneity and high frequencies of cytomegalovirus-specific CD8(+) T lymphocytes in healthy seropositive donors. $J$ Virol, 74:8140-8150.

Giorgi, J., Hutlin, L., McKeating, J., Johnson, T., and Owens, B. (1999). Shorter survival in advanced human immunodeficiency virus type 1 infection is more closely associated with $\mathrm{T}$ lymphocyte activation than with plasma virus burden or virus chemokine coreceptor usage. J Infect Dis, 179:859-870.

Gougeon, M. and Montagnier, L. (1993). Apoptosis in AIDS. Science, 260:12691270 .

Goulder, P., Tang, Y., Brander, C., Betts, M., Altfeld, M., Annamalai, K., Trocha, A., He, S., Rosenberg, E., Ogg, G., O'Callaghan, C., Kalams, S., McKinney, R., 
Mayer, K., Koup, R., Pelton, S., Burchett, S., McIntosh, K., and Walker, B. (2000). Functionally inert HIV-specific cytotoxic T lymphocytes do not play a major role in chronically infected adults and children. J Exp Med, 192:18191831.

Grabbe, S., Kampgen, E., and Schuler, G. (2000). Dendritic cells: multi-lineal and multi-functional. Immunol Today, 21:431-433.

Grassi, F., Hosmalin, A., McIlroy, D., Calvez, V., Debre, P., and Autran, B. (1999). Depletion in blood CD11c-positive dendritic cells from HIV-infected patients. AIDS, 13:759-766.

Gummuluru, S., Rogel, M., Stamatatos, L., and Emerman, M. (2003). Binding of human immunodeficiency virus type 1 to immature dendritic cells can occur independently of DC-SIGN and mannose binding C-type lectin receptors via a cholesterol-dependent pathway. J Virol, 77:12865-12874.

Haase, A. (1986). Pathogenesis of lentivirus infections. Nature, 322:130-136.

Haase, A. (1999). Population biology of HIV-1 infection: Viral and CD4 ${ }^{+} \mathrm{T}$ cell demographics and dynamics in lymphatic tissues. Annu Rev Immunol, 17:62556 .

Hazenberg, M., Otto, S., Hamann, D., Roos, M., Schuitemaker, H., de Boer, R., and Miedema, F. (2003a). Depletion of naive CD4 T cells by CXCR4-using HIV-1 variants occurs mainly through increased T-cell death and activation. AIDS, 17:1419-1424.

Hazenberg, M., Otto, S., van Benthem, B., Roos, M., Coutinho, R., Lange, J., Hamann, D., Prins, M., and Miedema, F. (2003b). Persistent immune activation in HIV-1 infection is associated with progression to AIDS. AIDS, 17:1881-1888.

Hellerstein, M., Hanley, M., Cesar, D., Siler, S., Papagerorgopoulus, C., Wieder, E., Schmidt, D., Hoh, R., Neese, R., Macallan, S., Deeks, S., and McCune, J. (1999). Directly measured kinetics of circulating $T$ lymphocytes in normal and HIV-1-infected humans. Nat Med, 5:83.

Hislop, A., Gudgeon, N., Callan, M., Fazou, C., Hasegawa, H., Salmon, M., and Rickinson, A. (2001). EBV-specific CD8+ T cell memory: relationships between epitope specificity, cell phenotype, and immediate effector function. J Immunol, 167:2019-2029.

Ho, D., Neumann, A., Perelson, A., Chen, W., Leonard, J., and Markowitz, M. (1995). Rapid turnover of plasma virions and CD4 lymphocytes in HIV-1 infection. Nature, 373:123-126.

Izmailova, E., Bertley, F., Huang, Q., Makori, N., Miller, C., Young, R., and Aldovini, A. (2003). HIV-1 Tat reprograms immature dendritic cells to express chemoattractants for activated T cells and macrophages. Nat Med, 9:191-197.

Janssen, E., Lemmens, E., Wolfe, T., Christen, U., von Herrath, M., and Schoenberger, S. (2003). CD4+ T cells are required for secondary expansion and memory in CD8+ T lymphocytes. Nature, 421:852-856. 
Jin, X., Wills, M., Sissons, J., and Carmichael, A. (1998). Progressive loss of IL-2-expandable HIV-1-specific cytotoxic T lymphocytes during asymptomatic HIV infection. Eur J Immunol, 28:3564-3576.

Johnson, R., Trocha, A., Yang, L., Mazzara, G., Panicali, D., Buchanan, T., and Walker, B. (1991). HIV-1 gag-specific cytotoxic T lymphocytes recognize multiple highly conserved epitopes. Fine specificity of the gag-specific response defined by using unstimulated peripheral blood mononuclear cell and cloned effector cells. J Immunol, 147:1512-1521.

Kaech, S. and Ahmed, R. (2003). Immunology. CD8 T cells remember with a little help. Science, 300:263-265.

Kalams, S., Buchibinder, S., Rosenberg, E., Billingsley, J., Colbert, D., Jones, N., Shea, A., Trocha, A., and Walker, B. (1999). Association between virus-specific cytotoxic T-lymphocyte and helper responses in human immunodeficiency virus type 1 infection. $J$ Virol, 73:6715-6720.

Kalams, S. and Walker, B. (1998). The critical need for CD4 help in maintaining effective cytotoxic T lymphocyte responses. J Exp Med, 188:2199-2204.

Katsikis, P., Wunderlich, E., Smith, C., and Herzenberg, L. (1995). Fas antigen stimulation induces marked apoptosis of $\mathrm{T}$ lymphocytes in human immunodeficiency virus-infected individuals. J Exp Med, 181:2029-2036.

Klein, M., van Baalen, C., Holwerda, A., Kerkhof Garde, S., Bende, R., Keet, I., Eeftinck-Schattenkerk, J.-K. M., Osterhaus, A., Schuitemaker, H., and Miedema, F. (1995). Kinetics of gag-specific cytotoxic T lymphocyte responses during the clinical course of HIV-1 infection: a longitudinal analysis of rapid progressors and long-term asymptomatics. J Exp Med, 181:1365-1372.

Kostense, S., Vandenberghe, K., Joling, J., Van Baarle, D., and Nanlohy, N. (2002). Persistent number of tetramer $+\mathrm{CD} 8(+) \mathrm{T}$ cells, but loss of interferon-gamma+ HIV-specific T cells during progression to AIDS. Blood, 99:2505-2511.

Koup, R., Safrit, J., Cao, Y., Andrews, C., McLeod, G., Borkowsky, W., Farthing, C., and Ho, D. (1994). Temporal association of cellular immune responses with the initial control of viremia in primary human immunodeficiency virus type 1 syndrome. $J$ Virol, 68:4650-55.

Kovacs, J., Lempicki, R., Sidorov, I., Adelsberger, J., and Herpin, B. (2001). Identification of dynamically distinct subpopulations of $\mathrm{T}$ lymphocytes that are differentially affected by HIV. J Exp Med, 194:1731-1741.

Kwon, D., Gregorio, G., Bitton, N., Hendrickson, W., and Littman, D. (2002). DC-SIGN-mediated internalization of HIV is required for trans-enhancement of $\mathrm{T}$ cell infection. Immunity, 16:135-144.

Leng, Q., Borkow, G., Weisman, Z., Stein, M., Kalinkovich, A., and Bentwich, Z. (2001). Immune activation correlates better than HIV plasma viral load with CD4 T-cell decline during HIV infection. J. AIDS, 27:389-397. 
Levy, J., Mackiewicz, C., and Barker, E. (1996). Controlling HIV pathogenesis: the role of the noncytotoxic anti-HIV response of $\mathrm{CD} 8^{+} \mathrm{T}$ cells. Immunol Today, $17: 217-224$.

Lieberman, J., Shankar, P., Manjunath, N., and Andersson, J. (2001). Dressed to kill? A review of why antiviral CD8 T lymphocytes fail to prevent progressive immunodeficiency in HIV-1 infection. Blood, 98:1667-1677.

Liu, Y. (2001). Dendritic cell subsets and lineages, and their functions in innate and adaptive immunity. Cell, 106:259-262.

Lore, K., Sonnerborg, A., Brostrom, C., Goh, L., Perrin, L., McDade, H., Stellbrink, H., Gazzard, B., Weber, R., Napolitano, L., van Kooyk, Y., and Andersson, J. (2002). Accumulation of DC-SIGN+CD40+ dendritic cells with reduced CD80 and CD86 expression in lymphoid tissue during acute HIV-1 infection. AIDS, 16:683-692.

Lutz, M. and Schuler, G. (2002). Immature, semi-mature and fully mature dendritic cells: which signals induce tolerance or immunity? Trends Immunol, 23:445-449.

McCune, J., Hanley, M., Cesar, D., Halvorsen, R., Hoh, R., Schmidt, D., Wieder, E., Deeks, S., Siler, S., Neese, R., and Hellerstein, M. (2000). Factors influencing T-cell turnover in HIV-1-seropositive patients. J Clin Invest, 105:R1.

McDonald, D., Wu, L., Bohks, S., KewalRamani, V., Unutmaz, D., and Hope, T. (2003). Recruitment of HIV and its receptors to dendritic cell-T cell junctions. Science, 300:1295-1297.

McIlroy, D., Autran, B., Cheynier, R., Wain-Hobson, S., Clauvel, J., Oksenhendler, E., Debre, P., and Hosmalin, A. (1995). Infection frequency of dendritic cells and CD4+ T lymphocytes in spleens of human immunodeficiency virus-positive patients. $J$ Virol, 69:4737-4745.

McMichael, A., Gotch, F., Noble, G., and Beare, P. (1983). Cytotoxic T-cell immunity to influenza. $N$ Engl $J$ Med, 309:13-17.

McMichael, A. and Rowland-Jones, S. (2001). Cellular immune responses to HIV. Nature, 410:980-987.

Mellman, I. and Steinman, R. (2001). Dendritic cells: specialized and regulated antigen processing machines. Cell, 106:255-258.

Meylan, P., Guatelli, J., Munis, J., Richman, D., and Kornbluth, R. (1993). Mechanisms for the inhibition of HIV replication by interferons- $\alpha,-\beta$, and $-\gamma$ in primary human macrophages. Virology, 193:138-148.

Migueles, S. and Connors, M. (2001). Frequency and function of HIV-specific CD8+ T cells. Imm Letters, 79:141-150.

Moriuchi, H., Moriuchi, M., Combadiere, C., Murphy, P., and Fauci, A. (1996). CD8 ${ }^{+}$T-cell-derived soluble factor(s), but not $\beta$-chemokines RANTES, MIP$1 \alpha$, and MIP-1 $\beta$, suppress HIV-1 replication in monocyte/macrophages. Proc Natl Acad Sci, 93:15341-15345. 
Ogg, G., Jin, X., Bonhoeffer, S., Rod Dunbar, P., Nowak, M., Monard, S., Segal, J., Cao, Y., Rowland-Jones, S., Cerundolo, V., Hurley, A., Markoqitz, M., Ho, D., Nixon, D., and McMichael, A. (1998). Quantitation of HIV-1-specific cytotoxic T lymphocytes and plasma load of viral RNA. Science, 279:2103-2106.

Pacanowski, J., Kahi, S., Baillet, M., Lebon, P., Deveau, C., Goujard, C., Meyer, L., Oksenhendler, E., Sinet, M., and Hosmalin, A. (2001). Reduced blood $\mathrm{CD} 23^{+}$(lymphoid) and CD11c $\mathrm{c}^{+}$(myeloid) dendritic cell numbers in primary HIV-1 infection. Blood, 98:3016-3021.

Pantaleo, G., Demarest, J., Schacker, T., Vaccarezza, M., Cohen, O., and Daucher, M. (1997a). The qualitative nature of the primary immune response to HIV infection is a prognosticator of disease progression independent of the initial level of plasma viremia. Proc Natl Acad Sci, 94:254-258.

Pantaleo, G., Graziosi, C., and Fauci, A. (1993). The immunopathogenesis of human immunodeficiency virus infection. $N$ Engl $J$ Med, 328:327-335.

Pantaleo, G., Soudeyns, H., Demarest, J., Vaccarezza, M., Graziosi, C., Paolucci, S., Daucher, M., Cohen, O., Denis, F., Biddison, W., Sekaly, R., and Fauci, A. (1997b). Accumulation of human immunodeficiency virus-specific cytotoxic T lymphocytes away from the predominant site of virus replication during primary infection. Eur J Immunol, 27:3166-3173.

Papagno, L., Appay, V., Sutton, J., Rostron, T., Gillespie, G., Ogg, G., King, A., Makadzange, A., Waters, A., Balotta, C., Vyakarnam, A., Easterbrrok, P., and Rowland-Jones, S. (2002). Comparison between HIV- and CMV-specific T cell responses in long-term HIV infected donors. Clin Exp Immunol, 130:509-517.

Papagno, L., Spina, C., Marchant, A., Salio, M., Rufer, N., Little, S., Dong, T., Chesney, G., Waters, A., Easterbrrok, P., Dunbar, P., Shepherd, D., Cerundolo, V., Emery, V., Griffiths, P., Conlon, C., McMichael, A., Richman, D., Rowland-Jones, S., and Appay, V. (2004). Immune activation and CD8+ T-cell differentiation towards senesence in HIV-1 infection. PLoS Biol, 2:Epub.

Patterson, S., Rae, A., Hockey, N., Gilmour, J., and Gotch, F. (2001). Plasmacytoid dendritic cells are highly susceptible to human immunodeficiency virus type 1 infection and release infectious virus. $J$ Virol, 75:6710-6713.

Perelson, A., Neumann, A., Markowitz, M., Leonard, J., and Ho, D. (1996). HIV1 dynamics in vivo: clearance rate, infected cell life-span, and viral generation time. Science, 271:1582-1586.

Phillips, A. (1996). Reduction of HIV concentration during acute infection: independence from a specific immune response. Science, 271:497-499.

Phillips, R., Rowland-Jones, S., Nixon, D., Gotch, F., Edwards, J., Ogunlesi, A., Elvin, J., Rothbard, J., Bangham, C., and Rizza, C. (1991). Human immunodeficiency virus genetic variation that can escape cytotoxic T-cell recognition. Nature, 354:453-459.

Pitcher, C., Quittner, C., Peterson, D., Connors, M., Koup, R., Maino, V., and Picker, L. (1999). HIV-1-specific CD4 ${ }^{+}$T cells are detectable in most individuals 
with active HIV-1 infection, but decline with prolonged viral suppression. Nat Med, 5:518-525.

Pope, M. (2003). Nefarious abuse. Nat Immunol, 4:729-730.

Quinn, T. (1997). Acute primary HIV infection. JAMA, 278:58-62.

Ribeiro, R., Mohri, H., Ho, D., and Perelson, A. (2002). In vivo dynamics of T cell activation, proliferation, and death in HIV-1 infection: why are CD4+ but not CD8+ T cells depleted. Proc Natl Acad Sci, 99:15572-15577.

Richman, D. (2000). Normal physiology and HIV pathophysiology of human T-cell dynamics. J Clin Invest, 105:565-6.

Ridge, J., Di Rosa, F., and Matzinger, P. (1998). A conditioned dendritic cell can be a temporal bridge between a $\mathrm{CD} 4^{+}$T-helper and a T-killer cell. Nature, 393:474-478.

Rosenberg, Y., Anderson, A., and Pabst, R. (1998). HIV-induced decline in blood CD4/CD8 ratios: viral killing or altered lymphocyte trafficking? Immunol Today, 19:10-16.

Roussanov, B., Taylor, J., and Giorgi, J. (2000). Calculation and use of an HIV-1 disease progression score. AIDS, 14:2715-2722.

Safrit, J. and Koup, R. (1995). Which immune responses control HIV replication? Curr Opin Immunol, 7:456-61.

Sallusto, F., Cella, M., Danieli, C., and Lanzavecchia, A. (1995). Dendritic cells use macropinocytosis and the mannose receptor to concentrate macromolecules in the major histocompatibility complex class II compartment: downregulation by cytokines and bacterial products. J Exp Med, 182:389-400.

Schacker, T., Collier, A., Hughes, J., Shea, T., and Corey, L. (1996). Clinical and epidemiologic features of primary HIV infection. Ann Intern Med, 125:257-264.

Schoenberger, S., Toes, R., van der Voort, E., Offringa, R., and Melief, C. (1998). T-cell help for cytotoxic T lymphocytes is mediated by CD40-CD40L interactions. Nature, 393:480-483.

Scott-Algara, D., Buseyne, F., Blanche, S., Rouzioux, C., Jouanne, C., Romagne, F., and Riviere, Y. (2001). Frequency and phenotyping of human immunodeficiency virus (HIV)-specific CD8 + T cells in HIV-infected children, using major histocompatibility complex class I peptide tetramers. J Infect Dis, 183:15651573.

Sester, M., Sester, U., Kohler, H., Schneider, T., Deml, L., Wagner, R., MuellerLantzsch, N., Pees, H., and Meyerhans, A. (2000). Rapid whole blood analysis of virus-specific CD4 and CD8 T cell responses in persistent HIV infection. AIDS, 14:2653-2660.

Sharpe, A. and Freeman, G. (2002). The B7-CD28 superfamily. Nat Rev Immunol, 2:116-126.

Shedlock, D. and Shen, H. (2003). Requirement for CD4 T cell help in generating functional CD8 T cell memory. Science, 300:337-339. 
Simmonds, P., Beatson, D., Cuthbert, R., Watson, H., and Reynolds, V. (1991). Determinants of HIV disease progression: six-year longitudinal study in the Edinburgh haemophilia/HIV cohort. Lancet, 338:1159-1163.

Sprent, J. (1973). Circulating T and B lymphocytes of the mouse, I. Migratory properties. Cell Immunol, 7:40-59.

Sprent, J. and Basten, A. (1973). Circulating T and B lymphocytes of the mouse, II. Lifespan. Cell Immunol, 7:10-39.

Stafford, M., Corey, L., Cao, Y., Daar, E., Ho, D., and Perelson, A. (2000). Modeling plasma virus concentration during primary HIV infection. $J$ Theor Biol, 203:285-301.

Sun, J. and Bevan, M. (2003). Defective CD $8+$ T cell memory following acute infection without CD4 T cell help. Science, 300:339-342.

Teleshova, N., Frank, I., and Pope, M. (2003). Immunodeficiency virus exploitation of dendritic cells in the early steps of infection. J Leukoc Biol, 74:683-690.

Trimble, L. and Lieberman, J. (1998). Circulating CD8 T lymphocytes in human immunodeficiency virus-infected individuals have impaired function and downmodulate CD3 zeta, the signaling chain of the T-cell receptor complex. Blood, 91:585-594.

van Baalen, C., Klein, M., Geretti, A., Keet, R., Miedema, F., van Els, C., and Osterhaus, A. (1993). Selective in vitro expansion of HLA class I-restricted HIV1 gag-specific CD8+ T cells: cytotoxic T-lymphocyte epitopes and precursor frequencies. AIDS, 7:781-786.

van Baarle, D., Kostense, S., van Oers, M., Hamann, D., and Miedema, F. (2002). Failing immune control as a result of impaired CD8+ T-cell maturation: CD27 might provide a clue. Trends Immunol, 23:586-591.

van Essen, D., Kikutani, H., and Gray, D. (1995). CD40 ligand-transduced costimulation of T cells in the development of helper function. Nature, 378:620623.

Wagner, L., Yang, O., Garcia-Zepeda, E., Ge, Y., Kalams, S., Walker, B., Pasternack, M., and Luster, A. (1998). $\beta$-chemokines are released from HIV-1-specific cytolytic T-cell granules complexed to proteoglycans. Nature, 391:908-911.

Walker, C., Moody, D., Stites, D., and Levy, J. (1986). CD8+ lymphocytes can control HIV infection in vitro by suppressing virus replication. Science, 234:1563-1566.

Wang, J. and Livingstone, A. (2003). Cutting edge: CD4+ T cell help can be essential for primary CD8+ $\mathrm{T}$ cell responses in vivo. J Immunol, 171:63396343 .

Webby, R., Andreansky, S., Stambas, J., Rehg, J., Webster, R., Doherty, P., and Turner, S. (2003). Protection and compensation in the influenza virus-specific CD8+ T cell response. Proc Natl Acad Sci, 100:7235-7240.

Wherry, E., Blattman, J., Murali-Krishna, K., van der Most, R., and Ahmed, R. (2003). Viral persistence alters CD8 T-cell immunodominance and tissue 
distribution and results in distinct stages of functional impairment. $J$ Virol, $77: 4911-4927$.

Wick, D. and Self, S. (2002). What's the matter with HIV-directed killer T cells. $J$ Theor Biol, 219:19-31.

Wodarz, D. (2001). Helper-dependent vs. helper-independent CTL responses in HIV infection: implications for drug therapy and resistance. $J$ Theor Biol, 213:447-459.

Wodarz, D. and Jansen, V. (2001). The role of T cell help for anti-viral CTL responses. $J$ Theor Biol, 211:419-432.

Wodarz, D., Klenerman, P., and Nowak, M. (1998). Dynamics of cytotoxic Tlymphocyte exhaustion. Proc $R$ Soc Lond B, 265:191-203.

Yang, O., Kalams, S., Rosenzweig, M., Trocha, A., Jones, N., Koziel, M., Walker, B., and Johnson, R. (1996). Efficient lysis of human immunodeficiency virus type-1-infected cells by cytotoxic T lymphocytes. $J$ Virol, 70:5799-5806.

Ye, P., Kourtis, A., and Kirchner, D. (2002). The effects of different HIV type 1 strains of human thymic function. AIDS Res Hum Retroviruses, 18:1239-1251.

Zajac, A., Blattman, J., Murali-Krsihna, K., Sourdive, D., Suresh, M., Altman, J., and Ahmed, R. (1998). Viral immune evasion due to persistence of activated T cells without effector function. J Exp Med, 188:2205-2213.

Zhang, D., Shankar, P., Xu, Z., Harnisch, B., Chen, G., Lange, C., Lee, S., Valdez, H., Lederman, M., and Liberman, J. (2003). Most antiviral CD8 T cells during chronic viral infection do not express high levels of perforin and are not directly cytotoxic. Blood, 101:226-235.

Zhang, L., Huang, Y., Yuan, H., Chen, B., Ip, J., and Ho, D. (1997). Genotypic and phenotypic characterization of long terminal repeat sequences from longterm survivors of human immunodeficiency virus type 1 infection. J Virol, 71:5608-5613. 